\title{
Vegetation Structure, Classification and Climatic Characteristics in Temperate-like Mountain Forests Dominated by Abies jaliscana in Western Mexico
}

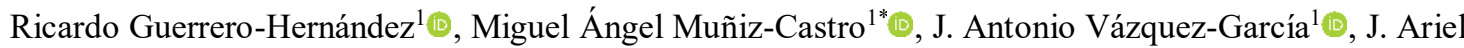 \\ Ruiz-Corral ${ }^{2} \oplus$, Gerardo Hernández-Vera ${ }^{1} \oplus$ \\ ${ }^{1}$ Universidad de Guadalajara, Departamento de Botánica y Zoología, Camino Ramón Padilla Sánchez \\ 2100, Zapopan, Jalisco, MEXICO \\ ${ }^{2}$ INIFAP, Campo Experimental Centro Altos Jalisco, Tepatitlán de Morelos, Jalisco, MEXICO \\ *Corresponding author: miguel.muniz@academicos.udg.mx
}

Received Date: 21.02.2019

Accepted Date: 19.06 .2019

\section{Abstract}

Aim of study: Examine patterns in woody species composition, vegetation structure, precipitation and temperature parameters over two fir forest elevation ranges and to discuss some biome-climate characteristics.

Area of Study: Field sampling was conducted in 20 Abies forest sites over two elevation ranges (Laguna Juanacatlan and Cerro La Bufa) in western Jalisco, Mexico.

Material and Methods: Using linear regressions, relationships between climate and fir forest structure were inferred. We examined vegetation structure complemented by cluster and indicator species analyses.

Main results: A total of 2378 stems belonging to 67 species were recorded, species richness and Shannon index were not different between localities. Cluster analysis suggest three forest types: upper montane cloud forest (UMCF), mixed fir-UMCF and fir forest. Fir basal area and abundance showed differences between localities. Reverse J-shaped size distribution pattern was found, except in the Cerro La Bufa lower belt, where a J-shaped pattern indicates low recruitment and high number of canopy individuals.

Highlights: The lower temperatures and increase in winter rainfall along the elevational gradient, enable an auspicious habitat for western Mexican fir forests.

Keywords: Abies jaliscana, Forest Structure, Precipitation of Coldest Quarter, Fir Forest Subtypes, Temperate-like Biome

\section{Meksika'nın Batısındaki Abies jaliscana'nın Egemen Olduğu Ilıman Ormanların Bitki Örtüsü Yapısı, SınıflandırıIması ve Iklimsel Özellikleri}

$\ddot{O} \mathbf{z}$

Çalışmanın Amacı: Farklı yükseltilerdeki iki farklı göknar ormanının odunsu türlerinin kompoziyonunun, vejetasyon yapısının, yağış ve sıcaklık parametreleri bakımından incelenmesi ve bazı biyom-iklim özelliklerini tartışmak.

Çalışma Alanı: Alan örneklemesi, Meksika'nın batı Jalisco kentinde iki yükseklik aralığında (Laguna Juanacatlan and Cerro La Bufa) seçilmiş yirmi farklı Abies ormanında yapılmıştır.

Materyal ve Yöntem: Doğrusal regresyonlar kullanılarak, iklim ve göknar ormanlarının yapısı arasındaki ilişkiler ortaya çıkarılmışıtır. Küme ve gösterge türlerinin analizleri ile tamamlanan bitki örtüsünün yapısı incelenmiştir.

Sonuçlar: 67 türe ait toplam 2378 birey kaydedilmiş olup, tür zenginliği ve Shannon indeksine göre bölgeler arasında farklılık gözlenmemiştir. Kümeleme analizi üç orman türü önermektedir: yüksek dağ ormanı, karışık göknar yüksek dağ ormanı ve göknar ormanı. Göknar bazal alanı ve bolluğu bölgeler arasında farklılıklar göstermiştir. Bir J-şekilli desenin işaret ettiği düşük stok ve yüksek sayıda kanopi bireyini gösteren Cerro La Bufa'nın alt kısımları haricinde, ters J-şekilli boyut dağılım modeli bulunmuştur.

Önemli vurgular: Düşük sıcaklıklar ve yükselti gradyanları boyunca artan kış yağışları, Meksika göknar ormanları için iyi bir yaşam alanı sağlamaktadır.

Anahtar kelimeler: Abies jaliscana, Orman Yapısı, En Soğuk Çeyreğin Yağışları, Göknar Ormanı Alt Türleri, Ilıman Benzeri Biyom 


\section{Introduction}

The distribution, diversity and structure of plant communities are strongly driven by climate (Holdridge, 1947; Stephenson, 1990; Peinado et al., 2012). Human impact and other environmental conditions such as physiographical, biological, and edaphic factors also play an important role (OlveraVargas, Figueroa-Rangel \& Vázquez-López, 2010; Linares, Carreira \& Ochoa, 2011). Vegetation science, based on size data and classification is a valuable tool that attempt to understand the forest structure, the establishment, development and the complex mosaic of different plant communities.

Mountain fir forests represent an ideal ecosystem for ecological research, particularly the study of the relationship between vegetation and climate. Fir forests structure has been widely studied in boreal (Kneeshaw and Bergeron, 1998; Antos and

Parish, 2002), mediterranean (Arista, 1995) and temperate regions (Pauley and Clebsch, 1990; Cogbill and White, 1991). In subalpine belts from North America and Asia, Abies lasiocarpa (Hook.) Nutt., A. fargesii Franch., A. georgei var. smithii (Viguié \& Gaussen) C.Y. Cheng, W.C. Cheng \& L.K. Fu and A. spectabilis Mirb. have been studied in terms of community structure, population dynamics and growth shifts (Whittaker and Niering, 1975; Dang, Zhang, Zhang, Jiang \& Zhang, 2010; Liang, Wang, Xu, Liu \& Shao, 2010; Gaire, Koirala, Bhuju \& Borgaonkar, 2014; Chhetri, Bista \& Cairns, 2016; Shrestha, Chhetri \& Bista, 2017). Other fir species in the western United States have been analyzed structurally, e.g. Abies magnifica A.Murray in California (Taylor and Halpern, 1991), A. concolor (Gordon \& Glend.) Lindl. ex Hildebr. and A. nobilis A. Dietr. in Oregon (Whittaker, 1960).

Mexican firs are influenced by tropical and mediterranean macrobioclimate (Peinado, Bartolomé, Delgadillo \& Aguado, 1994; Giménez de Azcárate and Ramírez, 2004; Giménez de Azcárate, Macías-Rodríguez \& Gopar-Merino, 2013), but due to their temperate and boreal affinity, they are restricted to high mountain zones with low temperatures. Therefore, this high elevation distribution compensates the lack of long and intense winters in tropical and subtropical latitudes (Rzedowski, 1978). Furthermore, these forests are relicts of a more extended distribution during the late Miocene (Graham, 1999); currently, the genus in Mexico probably grows at the threshold of its ecological and climatic requirements and needs cool microhabitats with high humidity. Moreover, this condition makes them more vulnerable to global climate change.

In Mexico, there are several studies on structural analysis, but very few descriptive ones about floristic composition (SánchezGonzález, López-Mata \& Vibrans, 2006; Encina-Domínguez, Encina-Domínguez, Mata-Rocha \& Valdés-Reyna, 2008; CuevasGuzmán et al., 2011; Guerrero-Hernández, González-Gallegos \& Castro-Castro, 2014). Furthermore, there is a lack of studies, mainly in subtropical and tropical latitudes, which classify fir forest subtypes and examine changes in temperature and precipitation in relation to elevation, which in turn could correspond with changes in fir forest structure. Only Ávila, Aguirre \& García (1994) analyzed environmental variables in relation to structure in Pico de Orizaba, Veracruz, Mexico, recognizing four physiognomic types (Abies hickelii-Pinus ayacahuite- $P$. patula forest, A. hickelii-P. pseudostrobus forest, $A$. hickelii monospecific forest and A. hickelii-Alnus jorullensis forest) of fir forest, however the temperature was measured for a very short period of time (10 days) and precipitation was overlooked.

We focused on relict forests with restricted distribution in climatic refugia, remaining from a wider distribution at the Miocene and middle Pliocene (Aguirre-Planter et al., 2012), such as those dominated by our target species, Abies jaliscana (Martínez) Mantilla, Shalisko \& A.Vázquez, which exhibits a remarkably isolated distribution in the western Mexican cloud forests (Guerrero-Hernández et al., 2014), Upper Montane Cloud forests sensu Ohsawa (1995). This fir species is locally abundant, is distributed only in steep coastal mountains and humid ravines from Jalisco (western Mexico), mainly on seaward and north-facing slopes at 1800-2400 m a.s.l., it has only been recorded in five areas on the western Trans-Mexican Volcanic Belt (TMVB) and the extreme northwestern range of the Sierra Madre del Sur, in the Pacific 
Basin (Vázquez-García, Shalisko, CuevasGuzmán, Muñiz-Castro \& Mantilla-Blandón, 2014). On the other hand, Velázquez, Toledo \& Luna (2000) state that fir forests in Mexico occur on very steep to moderate slopes at 2800-3500 m elevation.

In this study, we examine patterns in woody species composition, vegetation structure, and separately, analyze changes in precipitation and temperature over two narrow ranges of elevation at two areas with fir forest in western Jalisco, Mexico. Our specific aims were to (1) examine patterns in the structure of vegetation and woody species composition of the A. jaliscana forests from western Mexico (2) characterize fir population structure and asses differences between populations, and (3) look at changes in precipitation and temperature along elevation ranges and to discuss some biomeclimate characteristics for fir forests.

\section{Materials and methods}

Tree species

Abies jaliscana is a relict species belonging to the section Grandis, in a group from western Mexico which includes $A$. flinckii Rushforth and A. durangensis Martínez. A. jaliscana was previously known as A. guatemalensis Rehder var. jaliscana Martínez (1948); however Rushforth (1989) included this variety in A. flinckii populations, until Vázquez-García et al. (2014) provided morphological, phenological and geographical evidence to support the recognition of the western populations as a distinct species.

\section{Study Area}

This study was conducted in two locations at the north limit distribution of A. jaliscana: Laguna Juanacatlan (J), with the highest elevation at $2420 \mathrm{~m}, 55 \mathrm{~km}$ from the Pacific Ocean; mainly exposed to the windward inland slopes, and Cerro La Bufa (B), with the highest elevation at $2600 \mathrm{~m}, 40 \mathrm{~km}$ from the ocean; mainly exposed to the coast slopes. These sites are located in the western region of Jalisco state, Mexico, near the Pacific Ocean coast. The study area is located in the
Trans-Mexican Volcanic Belt western slopes where it overlaps with the northern limit of Sierra Madre del Sur, in western Mexico (Figure 1). The origin of these mountains is the result of intermediate mafic volcanism, covering the late Pliocene to the Quaternary (Gómez-Tuena, Orozco-Esquivel \& Ferrari, 2005). The soils have been classified as Andosols; the texture is sandy loam with high cation exchange capacity and high organic matter content (Guerrero-Hernández, 2016). The nearest meteorological station is located in the town of San Sebastian del Oeste at 1403 $\mathrm{m}$ a.s.l., which registered an annual mean temperature of $18.8{ }^{\circ} \mathrm{C}$ and total annual precipitation of $1354.7 \mathrm{~mm}$ in 38 years (SMN, 2017). Nevertheless, at the lower and upper belts of the study area, mean annual temperature values are 16.6 and $13.2{ }^{\circ} \mathrm{C}$ respectively, and the annual precipitation ranges from $1228 \mathrm{~mm}$ in the lower sites to $1183 \mathrm{~mm}$ in the upper sites, according to the downloaded bioclimatic data from WorldClim (Hijmans, Cameron, Parra, Jones \& Jarvis, 2005). As a comparative reference, a weather station was installed in the Abies forest stand J2374 (2374 $\mathrm{m}$ a.s.1.) for one year (2014-2015) and the annual mean temperature was $13.6{ }^{\circ} \mathrm{C}$. Additionally, the meteorological station from the town of Mascota, Jalisco (12 km SW from Juanacatlan locality) was checked to verify the bioclimatic data from WorldClim. The localities were selected by the dominance of $A$. jaliscana in fir forests and upper montane cloud forests along the altitudinal range in which thrives, from 1750 to $2450 \mathrm{~m}$, in two areas separated by Pinus-Quercus forests. Other criteria for selection of study sites were that they were old-growth forests with a good state of forest conservation, without evident or known human disturbances. However, in Cerro La Bufa locality a moderate level of disturbance was inferred, according to the presence of light demanding plant species in a few sites. The frequency and intensity of human disturbances as extensive cattle ranching, forest fires and logging are low or absent in the study sites. 


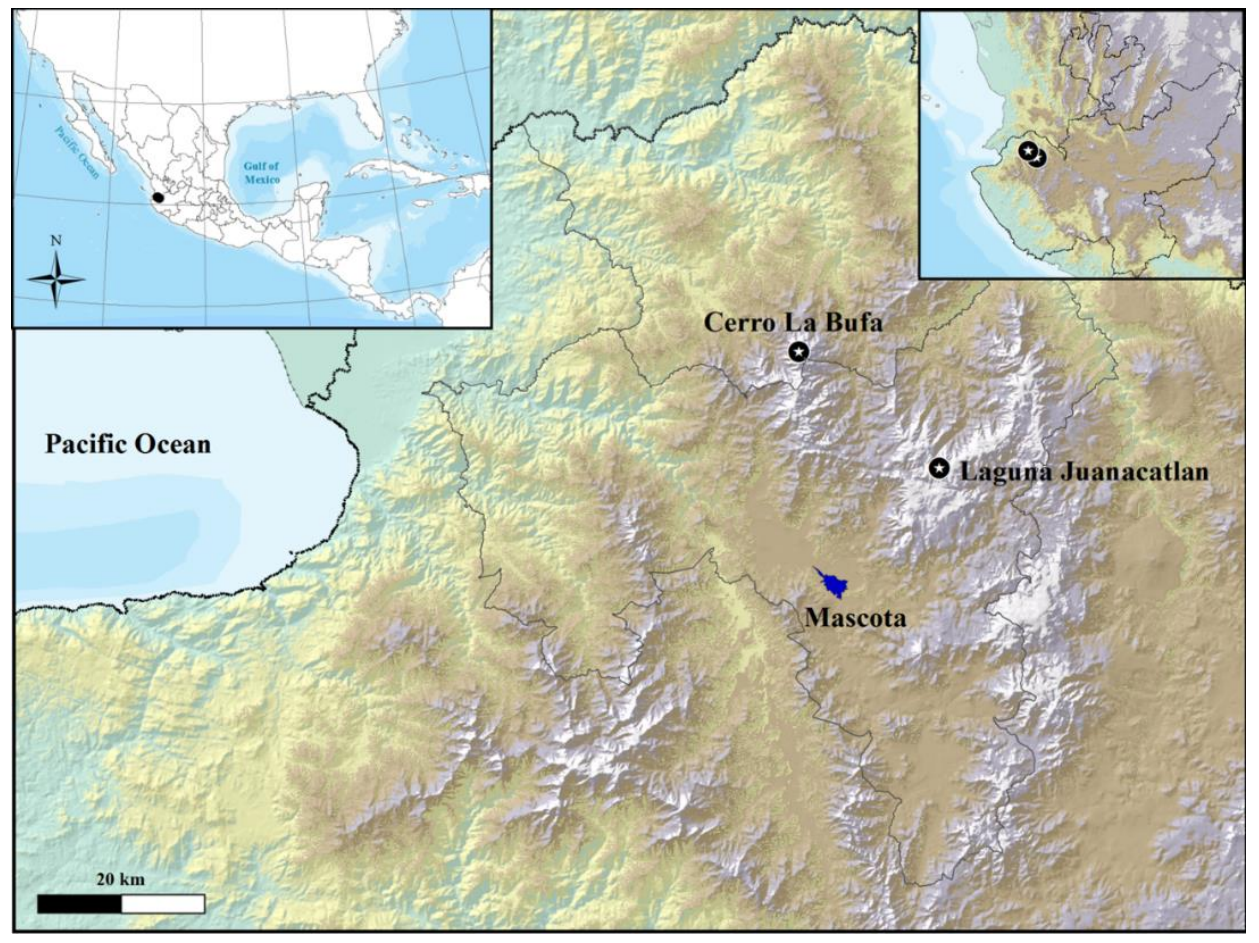

Figure 1. Northern distribution area and the two study localities of Abies jaliscana forests in western Mexico. Stars in a black circle indicate study sites.

\section{Field Sampling}

We used a stratified random sampling design, following Vázquez and Givnish (1998). After an extensive field reconnaissance, a total of 20 sites (ten forest stands per locality) were selected and located on windward slopes at two localities with fir forest remnants. The stands were established at Laguna Juanacatlan (2100$2413 \mathrm{~m}$ a.s.l.), and Cerro La Bufa (1755$2447 \mathrm{~m}$ a.s.l.) near to the summit $(2600 \mathrm{~m}$ elevation) (Table 1) (Figure 2). Within each site $(0.1$ ha, $60 \times 48 \mathrm{~m}$ area, subdivided in a grid of $12 \times 12 \mathrm{~m}$ squares) we randomly selected 10 out of 20 circular plots (each 0.01 ha and centered at each square), five from each of the two strata (upper and lower half of the grid). Within these circular plots all woody individuals $\geq 2.5 \mathrm{~cm}$ in DBH (ca. $1.3 \mathrm{~m})$ were measured and identified at species level. Growth-form (tree, shrub or vine) was also recorded for each species. Fertile specimens were collected as vouchers and deposited in the IBUG herbarium, at Universidad de Guadalajara, Mexico.

Table 1. Characteristics of the studied Abies jaliscana sites in western Jalisco, Mexico.

\begin{tabular}{|c|c|c|c|c|c|c|c|c|c|}
\hline Site & N Latitude & W Longitude & $\begin{array}{l}\text { Elev. } \\
(\mathrm{m})\end{array}$ & $\begin{array}{l}\text { Slope } \\
\left({ }^{\circ}\right)\end{array}$ & $\begin{array}{c}\text { Aspect } \\
\left({ }^{\circ}\right)\end{array}$ & $\begin{array}{c}\mathrm{AP} \\
(\mathrm{mm})\end{array}$ & $\begin{array}{c}\text { T mean } \\
\left({ }^{\circ}\right)\end{array}$ & $\begin{array}{l}\text { PCQ } \\
(\mathrm{mm})\end{array}$ & $\mathrm{S}$ \\
\hline \multicolumn{10}{|c|}{$\begin{array}{c}\text { Cerro La } \\
\text { Bufa }\end{array}$} \\
\hline 1 & $20^{\circ} 44^{\prime} 55.7^{\prime \prime}$ & $104^{\circ} 49^{\prime} 30^{\prime \prime}$ & 1750 & 25 & 327 & 1228 & 16.6 & 73 & 20 \\
\hline 2 & $20^{\circ} 44^{\prime} 42.2^{\prime \prime}$ & $104^{\circ} 49^{\prime} 13.1^{\prime \prime}$ & 1970 & 19 & 315 & 1215 & 15.1 & 79 & 18 \\
\hline 3 & $20^{\circ} 44^{\prime} 39.2^{\prime \prime}$ & $104^{\circ} 49^{\prime} 11.6^{\prime \prime}$ & 2020 & 33 & 315 & 1215 & 15.1 & 79 & 17 \\
\hline 4 & $20^{\circ} 44^{\prime} 33.3^{\prime \prime}$ & $104^{\circ} 49^{\prime} 9.1^{\prime \prime}$ & 2102 & 29 & 315 & 1215 & 15.1 & 79 & 14 \\
\hline
\end{tabular}


Table 1. (Continued)

\begin{tabular}{|c|c|c|c|c|c|c|c|c|c|}
\hline Site & N Latitude & W Longitude & $\begin{array}{c}\text { Elev. } \\
(\mathrm{m})\end{array}$ & $\begin{array}{c}\text { Slope } \\
\left({ }^{\circ}\right)\end{array}$ & $\begin{array}{c}\text { Aspect } \\
\left({ }^{\circ}\right)\end{array}$ & $\begin{array}{c}\mathrm{AP} \\
(\mathrm{mm})\end{array}$ & $\begin{array}{c}\text { T mean } \\
\left({ }^{\circ}\right)\end{array}$ & $\begin{array}{l}\text { PCQ } \\
(\mathrm{mm})\end{array}$ & $\mathrm{S}$ \\
\hline \multicolumn{10}{|c|}{$\begin{array}{l}\text { Cerro La } \\
\text { Bufa }\end{array}$} \\
\hline 5 & $20^{\circ} 44^{\prime} 17.2^{\prime \prime}$ & $104^{\circ} 49^{\prime} 35.2^{\prime \prime}$ & 2170 & 32 & 270 & 1220 & 14.7 & 82 & 11 \\
\hline 6 & $20^{\circ} 43^{\prime} 50.3^{\prime \prime}$ & $104^{\circ} 49^{\prime} 47.6^{\prime \prime}$ & 2265 & 35 & 358 & 1217 & 13.2 & 89 & 10 \\
\hline 7 & $20^{\circ} 44^{\prime} 2.2^{\prime \prime}$ & $104^{\circ} 48^{\prime} 52.4^{\prime \prime}$ & 2282 & 20 & 10 & 1215 & 14.5 & 79 & 13 \\
\hline 8 & $20^{\circ} 43^{\prime} 47.5^{\prime \prime}$ & $104^{\circ} 49^{\prime} 43.1^{\prime \prime}$ & 2345 & 31 & 341 & 1217 & 13.2 & 89 & 9 \\
\hline 9 & $20^{\circ} 43^{\prime} 51.7^{\prime \prime}$ & $104^{\circ} 49^{\prime} 38.9^{\prime \prime}$ & 2374 & 37 & 315 & 1217 & 13.2 & 89 & 12 \\
\hline 10 & $20^{\circ} 43^{\prime} 43.6^{\prime \prime}$ & $104^{\circ} 49^{\prime} 37.7^{\prime \prime}$ & 2447 & 29 & 329 & 1217 & 13.2 & 89 & 13 \\
\hline \multicolumn{10}{|l|}{$\begin{array}{l}\text { Laguna } \\
\text { Juanaca- } \\
\text { tlan }\end{array}$} \\
\hline 1 & $20^{\circ} 37^{\prime} 15.5^{\prime \prime}$ & $104^{\circ} 43^{\prime} 11.3^{\prime \prime}$ & 2100 & 28 & 317 & 1200 & 15.1 & 77 & 18 \\
\hline 2 & $20^{\circ} 36^{\prime} 45.8^{\prime \prime}$ & $104^{\circ} 41^{\prime} 59^{\prime \prime}$ & 2170 & 32 & 292 & 1188 & 14.3 & 80 & 14 \\
\hline 3 & $20^{\circ} 36^{\prime} 58.9^{\prime \prime}$ & $104^{\circ} 41^{\prime} 42.3^{\prime \prime}$ & 2256 & 31 & 297 & 1188 & 14.3 & 80 & 17 \\
\hline 4 & $20^{\circ} 36^{\prime} 58.1$ & $104^{\circ} 41^{\prime} 50.4^{\prime \prime}$ & 2280 & 21 & 280 & 1188 & 14.3 & 80 & 16 \\
\hline 5 & $20^{\circ} 36^{\prime} 57.2^{\prime \prime}$ & $104^{\circ} 41^{\prime} 42.1^{\prime \prime}$ & 2298 & 18 & 250 & 1188 & 14.3 & 80 & 12 \\
\hline 6 & $20^{\circ} 36^{\prime} 33.2$ & $104^{\circ} 42^{\prime} 5^{\prime \prime}$ & 2353 & 23 & 280 & 1193 & 14.6 & 79 & 13 \\
\hline 7 & $20^{\circ} 37^{\prime} 48.4^{\prime \prime}$ & $104^{\circ} 42^{\prime 2} .2^{\prime \prime}$ & 2360 & 28 & 280 & 1187 & 13.8 & 83 & 15 \\
\hline 8 & $20^{\circ} 37^{\prime} 36.6$ & $104^{\circ} 42^{\prime} 3.7^{\prime \prime}$ & 2374 & 10 & 160 & 1187 & 13.8 & 83 & 9 \\
\hline 9 & $20^{\circ} 37^{\prime} 48.1^{\prime \prime}$ & $104^{\circ} 41^{\prime} 48.4^{\prime \prime}$ & 2401 & 12 & 225 & 1183 & 13.9 & 81 & 10 \\
\hline 10 & $20^{\circ} 37^{\prime} 46.9^{\prime \prime}$ & $104^{\circ} 41^{\prime} 43.1^{\prime \prime}$ & 2413 & 12 & 100 & 1183 & 13.9 & 81 & 10 \\
\hline
\end{tabular}

Geographical coordinates, elevation, slope, aspect, annual precipitation (AP), annual mean temperature (T mean), precipitation of coldest quarter (PCQ) and species richness (S) 

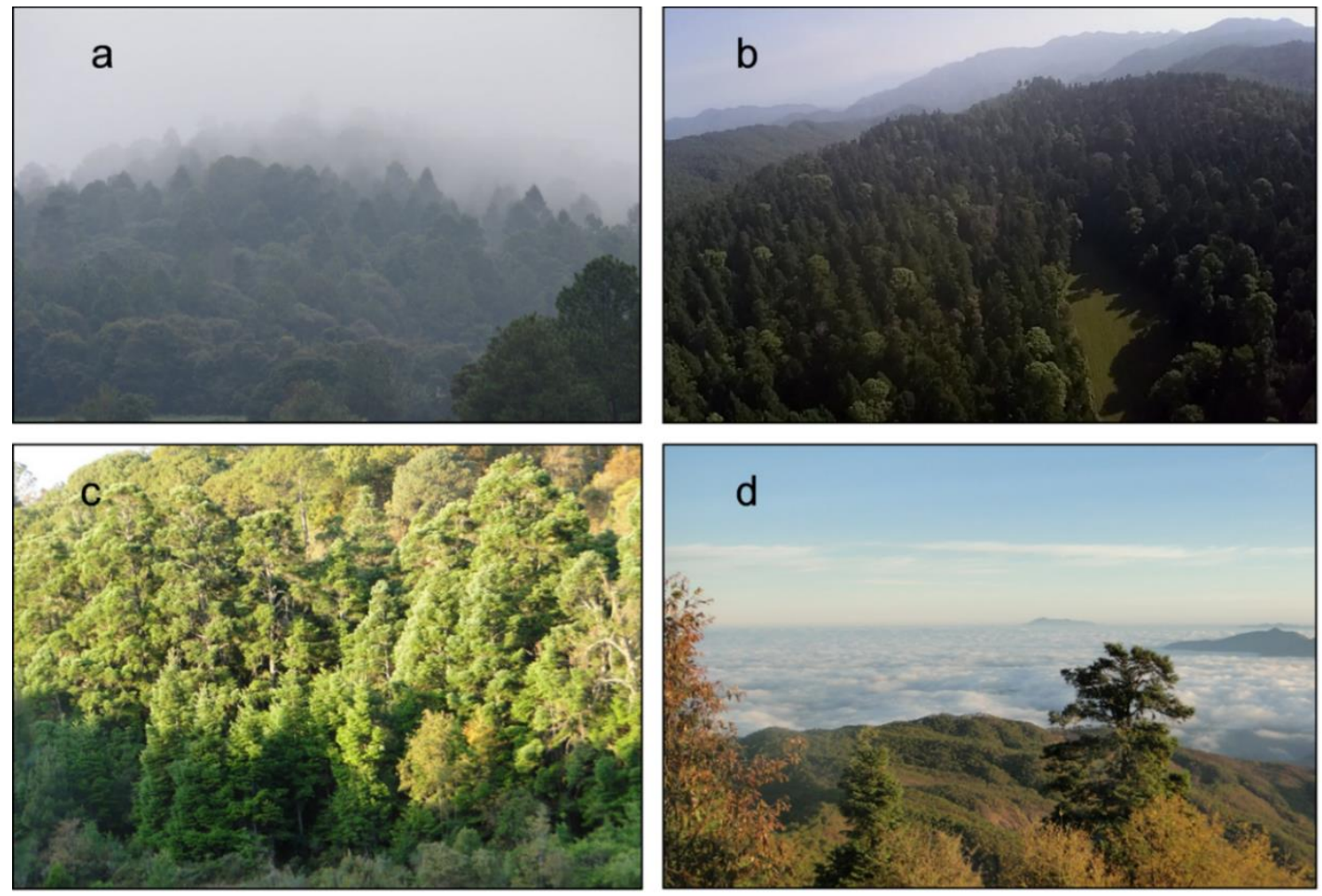

Figure 2. Landscape and stands pictures of Cerro La Bufa-Juanacatlan in western Jalisco, Mexico. (a) Fog incidence in a stand of Laguna Juanacatlan; (b) monospecific fir forest in Laguna Juanacatlan; (c) stand B2282 in Cerro La Bufa with high disturbance in the forest margins; (d) orographic cloud rising in Cerro La Bufa.

Climate information included the original 19 bioclimatic variables downloaded from the WorldClim database (Hijmans et al., 2005) for each site. The cell values from the rasters of the bioclimatic variables were obtained by the use of the "sample raster values" algorithm of Q-GIS program v. 2.18 (QGIS Development Team, 2018), using the point layer corresponding to the geographical coordinates of the sampling sites. No preprocessing or other derivation procedure was needed for the WorldClim bioclimatic layers. The precipitation of the warmest quarter, precipitation of the coldest quarter of the year, annual mean temperature and annual precipitation were selected using stepwise regression analysis and Pearson correlation, employing SIGMAPLOT V.11.0 (Systat Software Inc., 2008). These four climatic variables were selected instead of their correlated variables, being that several authors consider them as key variables for climatevegetation relationships (Whittaker, 1975; Hijmans et al., 2005; Williams-Linera, Toledo-Garibaldi \& Gallardo-Hernández,
2013; Toledo-Garibaldi and Williams-Linera, 2014). The precipitation of the warmest quarter and precipitation of the coldest quarter of the year are two important variables for plant survival and growth in tropical montane forests with high seasonality (Goldsmith, Matzke \& Dawson, 2013; Gotsch et al., 2014; Allen, Kirchner, Braun, Siegwolf \& Goldsmith, 2019).

WorldClim could not be the optimal data source to describe climatic variability in small spatial scales but certainly, it is the climate system with more precision all over the world (Hijmans et al., 2005). In addition, WorldClim was created by interpolating processes that include Anusplin methods which take into account the generation of smoothed surfaces of parameters (including precipitation); in these processes an elevation adjustment is considered, thus extrapolation of precipitation data is regulated by elevational values, ensuring the best possible estimation of precipitation for high sites even for those lacking a meteorological station 


\section{Data Analysis}

Species richness (S), Shannon Diversity Index $\left(\mathrm{H}^{\prime}\right.$, natural $\left.\log \right)$, fir basal area $\left(\mathrm{m}^{2} / \mathrm{ha}\right)$ and density (stems/ha) were calculated as descriptive measures of the woody community for each site. The Shannon Index and species richness were computed using EstimateS ver. 9.1.0 (Colwell, 2015). Statistical analyses for differences in mean values of such variables were performed using a t-test in SIGMAPLOT 11.0 (Systat Software Inc. 2008) with a level of significance $\alpha=$ 0.05 . Additionally, basal area and stem density were calculated per species within each stand. Fir trees were grouped into size classes at $10 \mathrm{~cm}$ intervals according to DBH in each site, the height of the trees was divided into six vertical strata: $1(1.3-10 \mathrm{~m}), 2(11-20$ m), 3 (21-30 m), 4 (31-40 m), 5 (41-50 m), 6 $(51-56 \mathrm{~m})$, and both $\mathrm{DBH}$ and vertical stratification was averaged by altitudinal belts. To assess changes in precipitation, temperature and fir basal area along elevation ranges, we fitted linear regressions between the independent variable $\mathrm{x}$ (elevation in our study) and the dependent variable y (climate variables and basal area in our study). The annual precipitation and annual mean temperature values that characterize the limit between the coniferous and the tropical upper montane cloud forest zones were examined using Holdridge life's zones (1947) and Whittaker biomes (1975).

Hierarchical agglomerative cluster analysis (McCune and Grace, 2002) was used to determine groups of sampling sites. This analysis was carried out using Sorensen (Bray-Curtis) distance measurements with the beta flexible linkage (beta $=-0.25$ ), which is the clustering linkage method of choice to avoid staggered groups. Indicator species analysis (ISA) was used as a quantitative, objective criterion to prune the dendrogram resulting from the hierarchical clustering. ISA yields an indicator value (between 0 and 1) with its statistical significance using a Monte Carlo technique based on 1,000 randomizations. Differences in species composition among groups of sites were tested with a multiresponse permutation procedure (MRPP). When all the species within groups are identical, the within-group agreement statistic $A$ reaches its maximum value $(A=1)$; when the heterogeneity within groups equals the level expected by chance, then $A=0$, and when there is more heterogeneity within groups than the level expected by chance, then $A<0$. In MRPP a $p$ value is given for each test group comparison. Classification and statistical tests were performed using the PC-ORD v. 6.0 software (McCune \& Grace, 2002).

\section{Results \\ Woody Species Composition}

A total of 2378 stems belonging to 67 species were recorded in 20 sites (2 ha); the genus Quercus was predominant with 10 species. The total species richness was higher in Cerro La Bufa (55 species) than in Laguna Juanacatlan (34 species), however, the estimated mean species richness $(\mathrm{S}, t=-$ $0.19902, P>0.05)$ and Shannon index $\left(\mathrm{H}^{\prime}, t\right.$ $=-1.92711, P>0.05)$ were not statistically different between localities (Figure 3c-d). The most frequent species were A. jaliscana (20 sites), Clethra hartwegii (10 sites), Meliosma dentata (7 sites), Oreopanax xalapensis (8 sites), Ostrya virginiana (8 sites), Quercus calophylla (7 sites), $Q$. castanea (9 sites), $Q$. obtusata (14 sites), Styrax argenteus (10 sites) and Symplocos citrea (8 sites) (Appendix). The plots with less tree species richness in Laguna Juanacatlan were recorded at the highest elevations (sites 8, 9 and 10), whereas in Cerro La Bufa were the sites 6 and 8 (Table $1)$.

\section{Classification}

The cluster analysis dendrogram based on species presence-absence in the sites was cut at a scale of $55 \%$ of remaining information, clustering sites in six groups (Figure 4); the homogeneity within groups was higher than the expected by chance (MRPP, $T=-6.91, A$ $=0.31, p<0.001)$. The first group included upper montane cloud forest sites located at the lowest elevations (sites $1-3$ at Cerro La Bufa, $\mathrm{B} 1750, \mathrm{~B} 1970, \mathrm{~B} 2020$ ); the second, third, fourth and sixth groups included mixed fir forest-upper montane cloud forest (sites 4, 5, 6, 7, 8, 9 and 10 at Cerro La Bufa; sites 1, 2, 3, 4, 6 and 7 at Laguna Juanacatlan). In contrast, one fraction of the fifth group included the most monospecific Abiesdominated forests $(5,8,9$ and 10 at $\mathrm{J}$ ) (Figure $4)$. The ISA identified ten species as strong indicators of the groups $(p<0.05)$ (Table 2$)$. 
From indicator species and classification analysis, forests were named based on two criteria, the first criterion is to name forests subtypes based on species dominants and in the second criterion we used the Ohsawa nomenclature (Ohsawa, 1991; 1995) for tropical montane cloud forests:

Upper montane cloud forest zone (group 1), at 1750-2020 m a.s.l. Evergreen species mixed with deciduous trees; evergreen elements such as Magnolia pacifica, Symplococarpon purpusii, Inga hintonii and Symplocos citrea were found in subcanopy and understorey. The deciduous elements were represented by Carpinus caroliniana, Ostrya virginiana, Quercus centenaria (González-Villarreal, 2018) and Quercus nixoniana. The canopy was dominated by Abies, Carpinus and Magnolia.

Mixed fir forest-upper montane cloud forest zone (groups 2, 3, 4, one fraction of group 5 and 6, plots J2100, J2170, J2256, J2280, J2353，J2360，B2170，B2265，B2282, B2345, B2374 and B2447), at 2100-2450 m a.s.l. In this zone, canopy was dominated extensively by $A$. jaliscana, which reach heights of $>50 \mathrm{~m}$. Despite the high dominance of fir trees, there was a well-developed understorey in different layers represented by species such as Arbutus xalapensis, Clethra hartwegii, Cleyera integrifolia, Ilex tolucana, Meliosma dentata, Myrsine juergensenii, Ostrya virginiana, Quercus obtusata, Symplocos citrea, Styrax argenteus and Ternstroemia lineata.

Coniferous forest zone (Abies forest; one fraction of group 5, plots J2998, J2374, J2401, $\mathrm{J} 2413$ ), at 2300-2420 $\mathrm{m}$ a.s.l. The coniferous forest zone was exclusively dominated in each layer by one conifer, i.e., A. jaliscana, although in the understorey, some trees with small sizes of the genera Pinus, Prunus,
Quercus and Styrax were found. In this forest zone, Abies reached up to $53 \mathrm{~m}$ in height and $1.45 \mathrm{~m} \mathrm{DBH}$.

Table 2. Indicator species (in bold) and fir forest groups determined by cluster analysis and indicator species analysis.

\begin{tabular}{|c|c|c|}
\hline Species & $\begin{array}{l}\text { Maximum } \\
\text { indicator } \\
\text { value }\end{array}$ & $P$ \\
\hline \multicolumn{3}{|l|}{ Group 1} \\
\hline Ageratina areolaris & 0.745 & 0.0284 \\
\hline Clethra fragans & 1 & 0.003 \\
\hline Magnolia pacifica & 0.542 & 0.6415 \\
\hline Miconia albicans & 0.791 & 0.0614 \\
\hline Quercus centenaria & 0.853 & 0.0098 \\
\hline Rumfordia floribunda & 0.661 & 0.0496 \\
\hline Xylosma flexuosa & 0.853 & 0.0104 \\
\hline \multicolumn{3}{|l|}{ Group 2} \\
\hline Quercus gentryi & 0.674 & 0.2 \\
\hline Quercus scytophylla & 0.674 & 0.1194 \\
\hline \multicolumn{3}{|l|}{ Group 3} \\
\hline Quercus martinezii & 0.853 & 0.0108 \\
\hline Telanthophora jaliscana & 0.503 & 0.3319 \\
\hline \multicolumn{3}{|l|}{ Group 4} \\
\hline Cupressus lusitanica & 0.674 & 0.2002 \\
\hline Quercus crassifolia & 1 & 0.0112 \\
\hline \multicolumn{3}{|l|}{ Group 5} \\
\hline Pinus leiophylla & 0.5 & 0.163 \\
\hline Prunus serotina & 0.504 & 0.1666 \\
\hline Quercus castanea & 0.692 & 0.0006 \\
\hline Quercus obtusata & 0.354 & 0.0422 \\
\hline Styrax argenteus & 0.598 & 0.0008 \\
\hline \multicolumn{3}{|l|}{ Group 6} \\
\hline Cleyera integrifolia & 0.535 & 0.146 \\
\hline Meliosma dentata & 0.593 & 0.0854 \\
\hline Oreopanax xalapensis & 0.535 & 0.1538 \\
\hline Symplocos citrea & 0.535 & 0.1476 \\
\hline
\end{tabular}



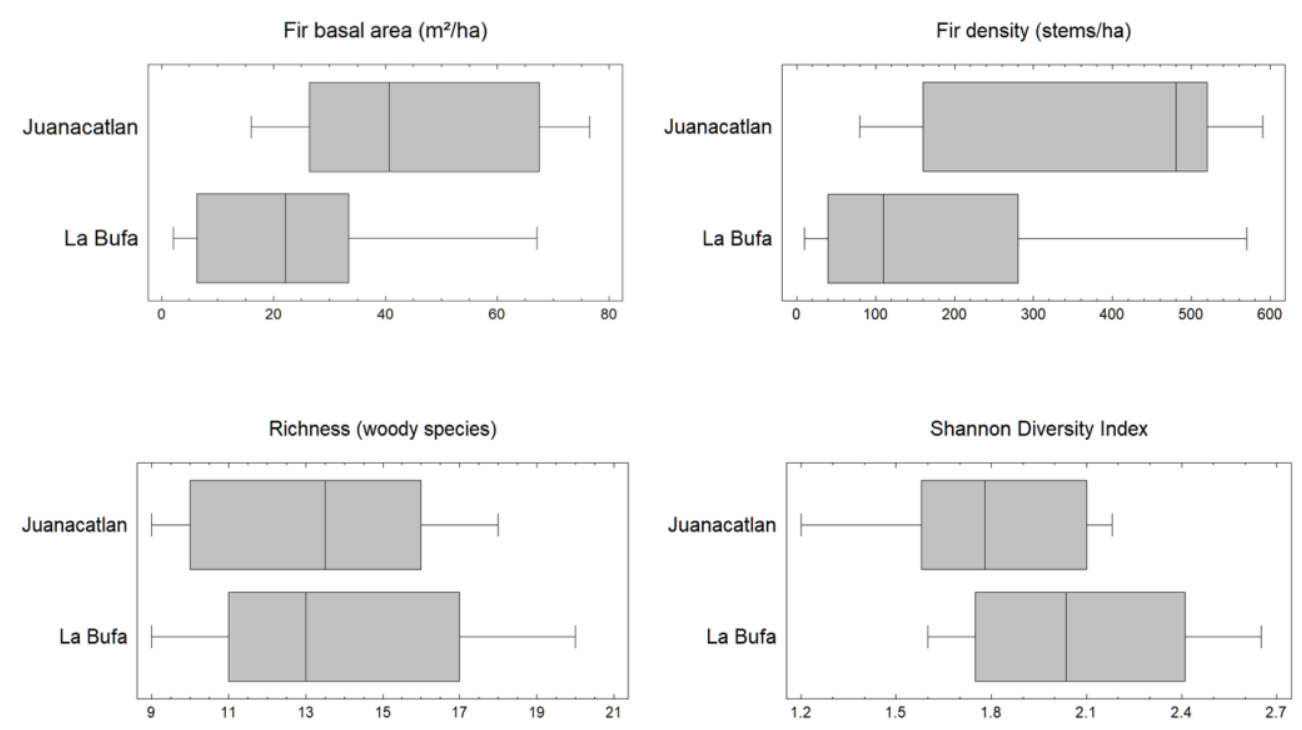

Figure 3. Box plots of basal area (a), stem density (b), species richness (c) and Shannon diversity index (d), of fir population per locality. Boxes depict standard deviation of the mean (filled circles); lines depict 95\% confidence interval; Cerro La Bufa (B) and Laguna Juanacatlan (J).

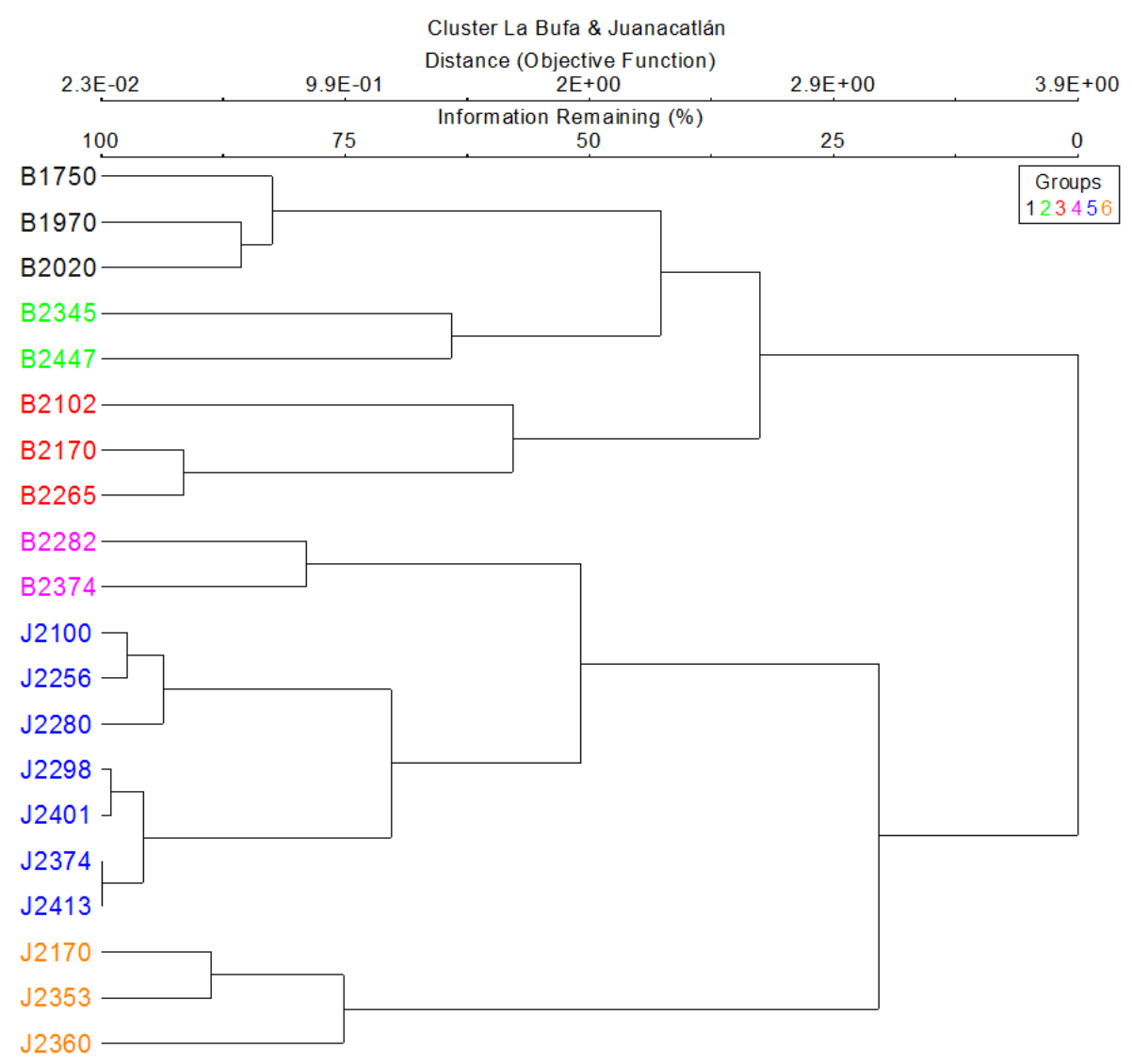

Figure 4. Cluster analysis dendrogram of the study sites between 1750 and $2447 \mathrm{~m}$ a.s.1. in fir forests of western Jalisco, Mexico, using Sorenson distance and beta flexible (-0.25) linkage method, cut at $50 \%$ of the remaining information scale. Cerro La Bufa (B) and Laguna Juanacatlan (J) 


\section{Fir Forest Structure}

In both localities, A. jaliscana exhibited the highest basal area followed by Quercus castanea, $Q$. centenaria, and $Q$. obtusata. Likewise, A. jaliscana showed the highest abundance followed by Clethra hartwegii, Styrax argenteus and Symplocos citrea (Table 3). Basal area of the fir population was higher in Laguna Juanacatlan than in Cerro La Bufa (BA, $t=2.40, P=0.027$; Figure $3 \mathrm{a}$ ); fir tree density also showed significant differences between locations $(\mathrm{N}, t=2.19, P=0.042)$, being higher in Laguna Juanacatlan (Figure 3b). The $\mathrm{DBH}_{\text {max }}$ in Laguna Juanacatlan was 1.45 and in $\mathrm{B}$ was $1.15 \mathrm{~m}$; likewise, the maximum values for height were 56 and $50 \mathrm{~m}$ at localities Laguna Juanacatlan and Cerro La Bufa, respectively. The fir diameter distributions within the studied forest are shown in Figures 5a-b. The fir population in Laguna Juanacatlan showed a reverse Jshaped distribution pattern at each elevation (lower and upper belts). At the lower belt, there was a higher proportion of individuals in the first categorycompared to those in the last category (Figure 5a). The upper belt had lower recruitment, higher survival in size classes 2 , 3 and twice as old individuals than the lower belt (Figure 5a). In contrast, in Cerro La Bufa, the lower belt showed low recruitment and survival with a high number of old individuals (J-shaped pattern). The middle and upper elevations showed a reverse J-shaped distribution pattern, but the middle belt showed more individuals in the last class than the other belts (Figure 5b). In Cerro La Bufa's upper belt, the small fir trees (DBH $<10 \mathrm{~cm}$ ) accounted for $35.7 \%$ of the total population of fir trees, whereas in Laguna Juanacatlan they represented only the $26.4 \%$. Regarding large trees $(\mathrm{DBH}>70 \mathrm{~cm})$, there was a lower proportion in Cerro La Bufa (4.1\%) compared to Laguna Juanacatlan (11.5\%).

The height distribution in Laguna Juanacatlan showed a reverse J-shaped pattern (multiage population) in both elevational belts (Figures 5c-d). In contrast, the canopy trees in Cerro La Bufa at the lower belt had the higher proportion with $57.1 \%$ (J-shape), than the middle belt, which showed a reverse J-shaped distribution pattern, the saplings $(1.3-10 \mathrm{~m}$ height) had the highest percentage of occurrence $(43.1 \%)$ in the middle belt. In the upper belt, the first and second stratum exhibited 40.1 and $34.7 \%$ of the individuals respectively, and the rest of strata had the least amount of stems. In the study area, fir basal area exhibits a slight increasing trend in relation to elevation $\left(\mathrm{R}^{2}=0.23, P=0.033\right)$ (Figure 6). In summary, basal area, tree density, height and DBH varied among the different elevational belts in both localities (Table 4).

\section{Climatic Characteristics}

In both localities, annual precipitation values are over $1100 \mathrm{~mm}$ and the highest elevation sites exhibited annual mean temperature values (AMT) below $14{ }^{\circ} \mathrm{C}$ (Table 1). The AMT did not show significant differences between the two localities (MannWhitney $U=45.5, P=0.74$ ) and the annual precipitation was higher in Cerro La Bufa than in Laguna Juanacatlan (Mann-Whitney $U=$ $0.00, P<0.001)$. In both localities, the AMT had a decreasing monotonic pattern in relation to elevation (Figures 7a-b). 

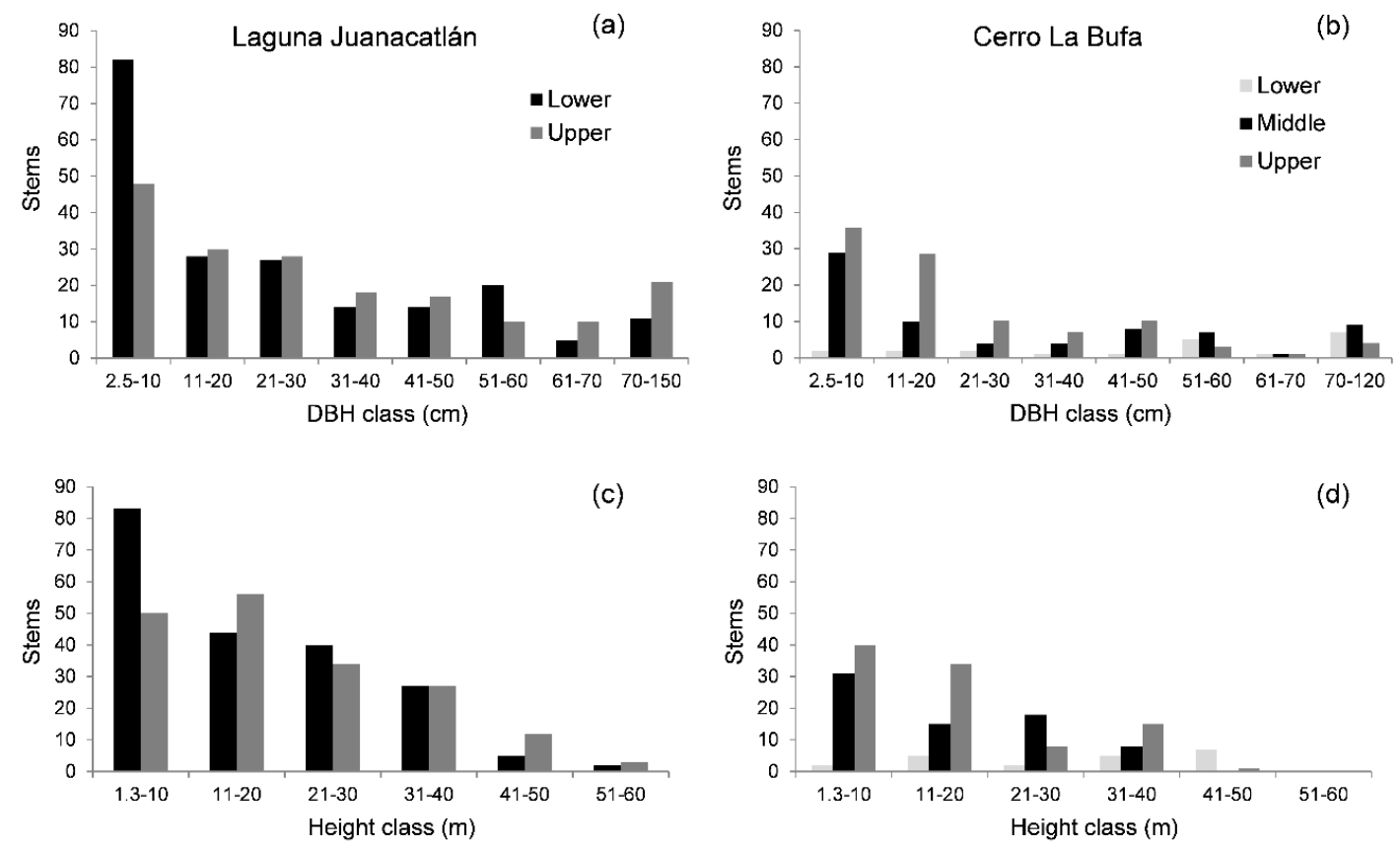

Figure 5. Size class distribution (DBH) of the fir trees at different elevation belts in Laguna Juanacatlan (a) and Cerro La Bufa (b) in western Jalisco, Mexico. Size class: $1=2.5-10 \mathrm{~cm}, 2=$ $11-20 \mathrm{~cm}, 3=21-30 \mathrm{~cm}, 4=31-40 \mathrm{~cm}, 5=41-50 \mathrm{~cm}, 6=51-60 \mathrm{~cm}, 7=61-70 \mathrm{~cm}, 8>70 \mathrm{~cm}$. Height class distribution of the fir trees at different elevation belts in Laguna Juanacatlan (c) and Cerro La Bufa (d) in western Jalisco, Mexico. Height stratum: $1=1.3-10 \mathrm{~m}, 2=11-20 \mathrm{~m}, 3=$ $21-30 \mathrm{~m}, 4=31-40 \mathrm{~m}, 5=41-50 \mathrm{~m}, 6=51-60 \mathrm{~m}$. Y-axis shows the total number of stems per locality and elevational belt.

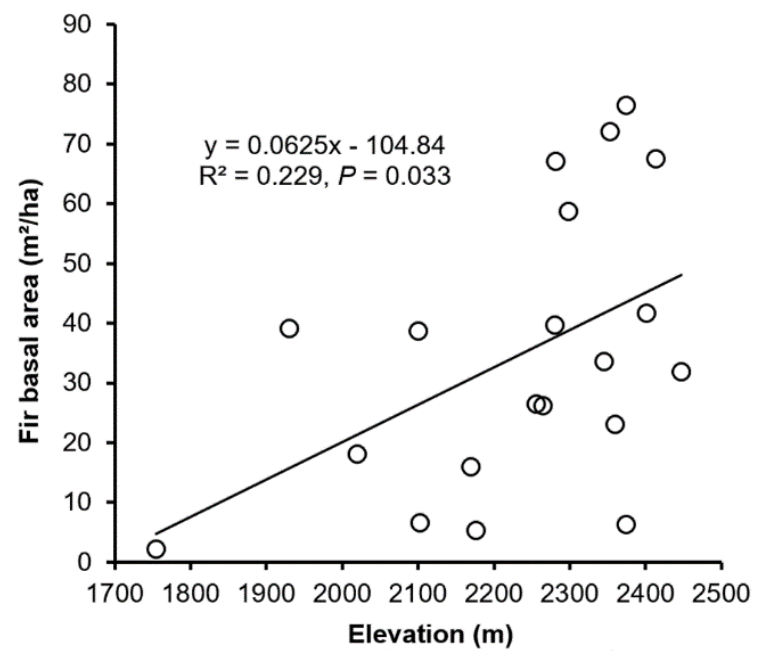

Figure 6. Scatterplot of fir basal area along elevation range for 20 stands in western Mexico. 
Table 3. Tree species composition of the fir (A. jaliscana) forests in western Jalisco, Mexico.

\begin{tabular}{|c|c|c|c|c|}
\hline \multicolumn{5}{|l|}{$\begin{array}{l}\text { Laguna } \\
\text { Juanacatlan }\end{array}$} \\
\hline Species & $\begin{array}{l}\text { Density } \\
\text { (stems/ } \\
\text { ha) }\end{array}$ & $\begin{array}{l}\text { Basal } \\
\text { area } \\
\left(\mathrm{m}^{2} /\right. \\
\text { ha })\end{array}$ & $\begin{array}{l}\text { Relat } \\
\text { ive } \\
\text { densi } \\
\text { ty } \\
(\%) \\
\end{array}$ & $\begin{array}{l}\text { Relat } \\
\text { ive } \\
\text { basal } \\
\text { area } \\
(\%)\end{array}$ \\
\hline Abies jaliscana & 383 & 46.04 & 26.62 & $\begin{array}{l}68.9 \\
3 \\
\end{array}$ \\
\hline Quercus obtusata & 60 & 4.57 & 4.17 & 6.84 \\
\hline Quercus castanea & 28 & 2.2 & 1.95 & 3.3 \\
\hline Pinus pseudostrobus & 14 & 2.18 & 0.97 & 3.26 \\
\hline Clethra hartwegii & 110 & 2.04 & 7.64 & 3.05 \\
\hline Arbutus xalapensis & 30 & 1.8 & 2.08 & 2.69 \\
\hline Symplocos citrea & 88 & 1.36 & 6.12 & 2.04 \\
\hline Styrax argenteus & 394 & 0.96 & 27.38 & 1.43 \\
\hline Pinus oocarpa & 5 & 0.88 & 0.35 & 1.31 \\
\hline Ostrya virginiana & 14 & 0.8 & 0.97 & 1.19 \\
\hline Other 24 species & 313 & 3.98 & 21.75 & 5.96 \\
\hline Totals & 1439 & 66.81 & 100 & 100 \\
\hline \multicolumn{5}{|l|}{ Cerro La Bufa } \\
\hline Abies jaliscana & 191 & 23.6 & 20.34 & $\begin{array}{l}52.0 \\
7 \\
\end{array}$ \\
\hline Quercus centenaria & 61 & 4.13 & 6.5 & 9.11 \\
\hline Clethra hartwegii & 46 & 2.77 & 4.9 & 6.12 \\
\hline Quercus martinezii & 39 & 2.12 & 4.15 & 4.68 \\
\hline Quercus scytophylla & 15 & 1.48 & 1.6 & 3.27 \\
\hline Arbutus xalapensis & 12 & 1.24 & 1.28 & 2.72 \\
\hline Quercus obtusata & 20 & 1.14 & 2.13 & 2.51 \\
\hline Ostrya virginiana & 51 & 1.11 & 5.43 & 2.46 \\
\hline Quercus rugosa & 20 & 1.04 & 2.13 & 2.29 \\
\hline Meliosma dentata & 4 & 0.59 & 0.43 & 1.31 \\
\hline Other 45 species & 480 & 6.1 & 51.11 & $\begin{array}{l}13.4 \\
6 \\
\end{array}$ \\
\hline Totals & 939 & 45.32 & 100 & 100 \\
\hline
\end{tabular}

The annual precipitation occurred without significant changes along the elevational range in Cerro La Bufa, but in Laguna Juanacatlan a decreasing trend was detected $(P=0.015)$ (Figure $7 \mathrm{~d})$ and the precipitation of the warmest quarter in Cerro La Bufa decreased $(P<0.001)$ regarding elevation (Figure 7c). In contrast, the precipitation of the coldest quarter had a significant increase along the elevational range in both localities. Maximum temperature of warmest month and minimum temperature of coldest month were highly correlated with annual mean temperature; therefore they were excluded from the results.

The climatic parameters of these forests were examined using Holdridge life's zones. Sites at both localities are located in the warm temperate moist forest zone (annual mean temperature $=13.2-16.6{ }^{\circ} \mathrm{C}$, annual precipitation $=1183-1217 \mathrm{~mm})($ Table 1$)$, and some of the highest elevation stands thrive relatively near to the cool temperate belt. Only one low-altitude plot (co-dominant species Magnolia pacifica, Quercus centenaria and Pinus douglasiana) exhibited annual mean temperature values above $16{ }^{\circ} \mathrm{C}$, near to the limit of the subtropical-warm temperate belts $\left(18{ }^{\circ} \mathrm{C}\right)$; the rest of the sites had Abiesmicrophyllous-notophyllous trees forest (with understory species as Clethra hartwegii, Ilex tolucana, Meliosma dentata, Ostrya virginiana, Styrax argenteus and Symplocos citrea, $15.1-14.0^{\circ} \mathrm{C}$ ) and Abies monospecific forest $\left(14.5-13.8^{\circ} \mathrm{C}\right)$.

\section{Discussion}

Fir forests from western Mexico mix with broadleaved tropical montane cloud forest in the lower and middle belts of their altitudinal distribution (Vázquez-García, VargasRodríguez \& Aragón, 2000; Cuevas-Guzmán et al., 2011). In this study we have documented an interesting replacement from the tropical upper montane evergreen microphyllous forests (e.g. indicator elements such as Ilex, Meliosma, Myrsine and Symplocos) to "humid temperate conifer" forest towards higher elevations. This replacement has also been observed in montane forests of south Mexico, western Guatemala and Southeast Asia (Hartshorn, 1988; Ohsawa, 1995). It is important to mention that pines and oaks also thrive in the canopy, subcanopy and understorey, a pattern found by other researchers in the west, center and northeast of Mexico in fir forests (Sánchez-González et al., 2006; EncinaDomínguez et al., 2008; Cuevas-Guzmán et al., 2011).

The cluster analysis dendrogram shows that groups 4 and 5 are very similar because of the high abundance of fir individuals. However, some of the highest elevation plots $\mathrm{J} 2374$, J2401 and J2413 (8, 9 and 10 respectively, group 5) had the lowest woody species richness in Laguna Juanacatlan and the highest basal area for Abies; they also tend 
to be nearly monospecific forests. These attributes coincide with the findings by Arista (1995), Ávila et al. (1994) and CuevasGuzmán et al. (2011) in high elevation stands where other fir species occur. In contrast, in Cerro La Bufa there was a peak with the highest fir basal area and abundance at 2282 $\mathrm{m}$ a.s.1. (plot B2282), above that elevation there was a decrease in basal area (in plots B2345, B2374 and B2447). A similar result was reported by Dang et al. (2010) on Abies fargesii in the Qinling Mountains, China. Some authors have identified this trend in peaks above 3500-3600 $\mathrm{m}$ a.s.1. at the TMVB, where the precipitation, species richness, fir basal area and stem density decline abruptly towards higher elevations (SánchezVelásquez, Pineda-López \& HernándezMartínez, 1991; Sánchez-González and López-Mata, 2003; Toledo- Garibaldi \& Williams-Linera, 2014). This trend could be attributed to lower moisture conditions, very low atmospheric pressure and lower temperatures above that elevational level, which might be a limiting factor for firs. However, in Cerro La Bufa, this trend was unexpected since western Mexican firs do not reach these altitudinal levels because there are not mountains higher than $3000 \mathrm{~m}$ in the region. Furthermore, it is notable the higher density and basal area for A. jaliscana in the upper belt elevation in Laguna Juanacatlan, while in Cerro La Bufa a higher dominance was observed in the middle belt (Table 4). A peculiarity in Cerro La Bufa was the high abundance of heliophilous species, such as Ageratina areolaris, Roldana angulifolia and Rumfordia floribunda, which suggests high disturbance likely due to an anthropogenic origin and an abrupt relief, with slopes greater than 30 degrees in five plots (Table 1). We found significant differences in basal area and density of fir populations between the two locations, being Laguna Juanacatlan the one with the higher values in both structural variables. This result was not expected either, because Cerro La Bufa has a wider elevational range, higher amount of rainfall and it is located slightly closer to the ocean that Laguna Juanacatlan (Table 1, Figure 1 and Figure 8); this water availability and high humidity, in theory, would facilitate the presence, growth and biomass production of fir forest (Toledo-Garibaldi \& WilliamsLinera, 2014). A possible explanation is that the natural reservoir at Laguna Juanacatlan might play an important role in a better development of fir trees; however, further studies will be necessary to assess that hypothesis.

Table 4. Structural characteristics of A. jaliscana population at different altitudinal belts in Cerro La Bufa and Laguna Juanacatlan in western Jalisco, Mexico. \pm symbol indicates standard deviation; DBH is diameter at breast height; BA is basal area.

\begin{tabular}{llllll}
\hline Altitudinal belt & Elevation $(\mathrm{m})$ & DBH $(\mathrm{cm})$ & $\mathrm{BA}\left(\mathrm{m}^{2} / \mathrm{ha}\right)$ & Density $($ stems $/ \mathrm{ha})$ & Height $(\mathrm{m})$ \\
\hline $\begin{array}{llllll}\text { Cerro La Bufa } \\
\text { Lower belt }\end{array}$ & & & & & \\
\hline Middle belt & $1750-2000$ & $52.76 \pm 1.33$ & 19.76 & 70 & $30.90 \pm 6.69$ \\
\hline Upper belt & $2100-2300$ & $30.40 \pm 7.14$ & 26.26 & 180 & $16.52 \pm 2.58$ \\
\hline Laguna Juanacatlan & $2300-2449$ & $21.87 \pm 4.28$ & 23.89 & 326.66 & $15.89 \pm 2.01$ \\
\hline Lower belt & $2100-2300$ & $24.69 \pm 3.20$ & 35.91 & 402 & $17.78 \pm 1.67$ \\
\hline Upper belt & $2300-2413$ & $33.03 \pm 4.33$ & 56.18 & 364 & $20.91 \pm 1.84$ \\
\hline
\end{tabular}



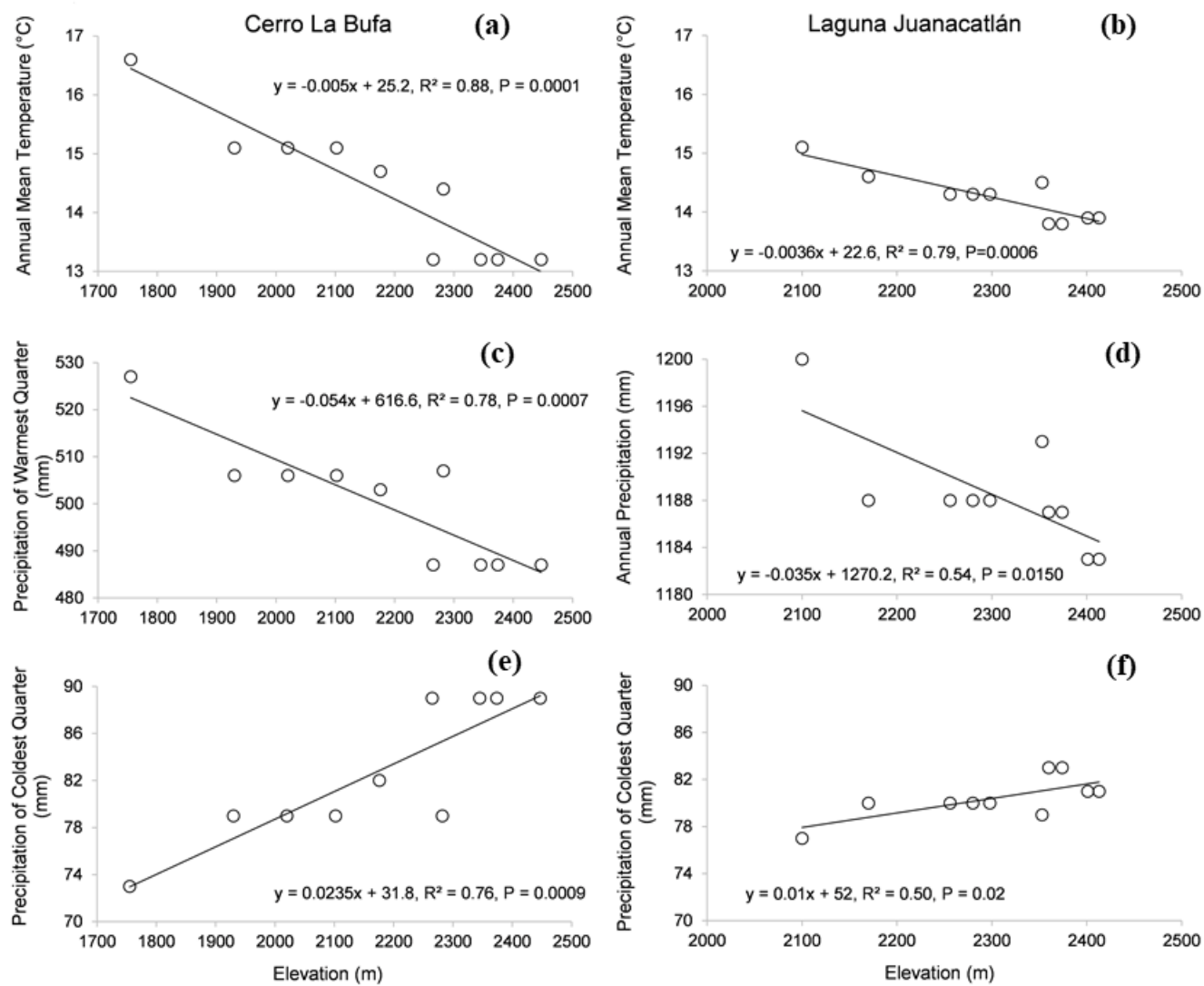

Figure 7. Trends in annual mean temperature $\mathrm{BIO} 1(\mathrm{a}, \mathrm{b})$, precipitation of warmest quarter BIO 18 (c), annual precipitation BIO 12 (d), and precipitation of coldest quarter BIO 19 (e, f) in relation to elevation. Cerro La Bufa (B) and Laguna Juanacatlan (J).

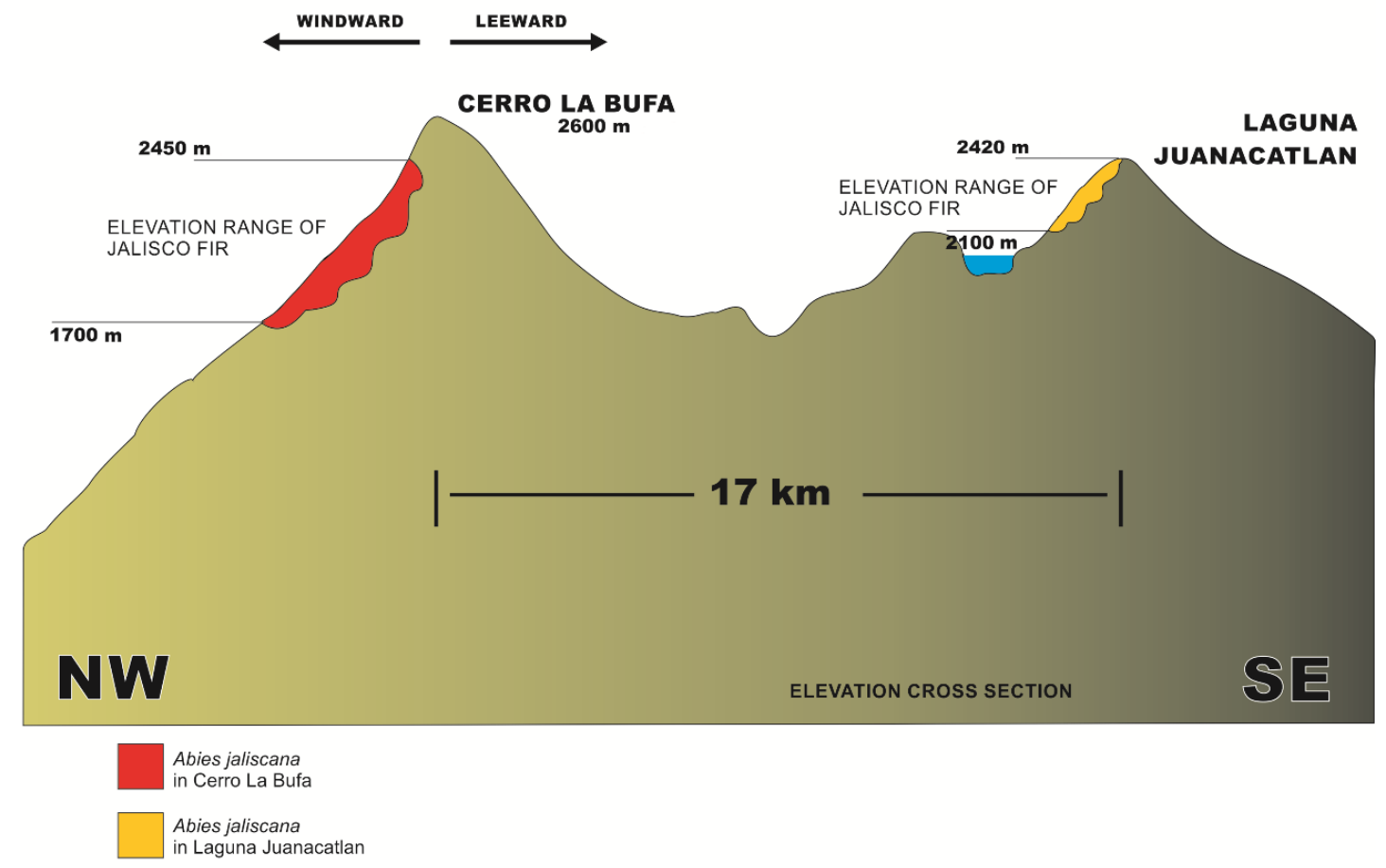

Figure 8. Elevational distribution of the two localities with western Mexican fir forest, which they are oriented towards the windward and are separated by $17 \mathrm{~km}$.

In Mexican fir forests some authors have (Encina-Domínguez et al., 2008; Cuevasfound a J-inverse shaped size distribution

Guzmán et al., 2011), suggesting a good 
regenerative capacity of populations and a regime of mild disturbance, because Abies seedlings are generally favored by some canopy openings, a condition which facilitates their establishment and growth (LaraGonzález, Sánchez-Velásquez \& CorralAguirre, 2009). The lower belt stands in Laguna Juanacatlan also showed high recruitment but low survival, suggesting some degree of competition with species characteristic of cloud forest, whereas in the upper belt there was a high survival in the categories with the largest trees even in the canopy trees, which were twice abundant than the lower belt. On the other hand, Dang et al. (2010) found a bell-shaped size distribution along an elevational gradient in the Qinling Mountains of China, attributing this pattern to a recruitment pulse due to a period of logging during the 19th century. In contrast, at Cerro La Bufa the lower belt had the highest concentration of individuals in the canopy layer, whereas the middle and upper belts showed a J-inverse pattern. The absence of fir saplings and low recruitment at the lower belt might be attributed to the high competition with high-size heliophilous shrub species in the understory and to the shade of canopy broad-leaved trees. Most of the Mexican fir forests develop in pure stands (Rzedowski, 1978), but A. jaliscana shares its distribution in the lower elevation level with several broad-leaved trees and as it reaches a higher elevation, it becomes a nearly monospecific community.

Some authors have stated that boreal forest spreads through the cordilleras of western North America to southern Mexico, and that most of the Mexican highlands are covered by boreal forest (e.g. Picea and Abies) (Leopold, 1950; Lomolino, Riddle, Whittaker \& Brown, 2010). However, this assertion is questioned because the upper limit of annual mean temperature for the boreal forest is around 2 to $3{ }^{\circ} \mathrm{C}$, which is closer to that reported for temperate subalpine forest (e.g. spruce-fir forest in the mountains of eastern North America) (Cogbill \& White, 1991). On the other hand, alpine and subalpine belts in the tropics and subtropics have a temperature range close to the boreal forests or subarcticsubalpine needle-leaved forests $\left(3-6{ }^{\circ} \mathrm{C}\right)$
(Holdridge, 1947; Whittaker, 1975; Wolfe, 1979). In contrast, the Mexican "boreal forests", mainly composed by Abies religiosa populations (Section Oiamel), have an annual mean temperature of $9-10{ }^{\circ} \mathrm{C}$ at their upper limit of elevational distribution (SánchezVelásquez et al., 1991; Sánchez-González \& López-Mata, 2003). These forests can be more accurately referred to as cool-temperate forest than "boreal forest". Furthermore, in the present study we observed that A. jaliscana forests are warm temperate moist forests (annual mean temperature: $12-18{ }^{\circ} \mathrm{C}$, see (Holdridge, 1947)), rather than "boreal", in a subtropical montane zone, and they form nearly monospecific forests in areas with 14.5 to $13.8{ }^{\circ} \mathrm{C}$ of annual mean temperature and 1215 to $1183 \mathrm{~mm}$ of annual precipitation. Therefore, according to climate and the biome concept, Mexican fir forests have more affinity with the "temperate rain forest" biome (TRF-biome) (Whittaker, 1975; Lomolino et al., 2010) than with the boreal forest. In the current study, the genera Cleyera, Magnolia, and others like Symplocos and Ternstroemia, are also found in the downward transition to the upper montane cloud forest. Some examples of the former are the mixed broadleaved evergreen and coniferous forests of southeastern and eastern Asia (e.g. Abies firma, Cleyera japonica, Fagus japonica and Magnolia hypoleuca) (Takahashi and Okuhara, 2012). Similar temperature and precipitation parameters in our study area have also been documented in the Redwood forest in western North America, with populations of Abies grandis (Table 5) (Noss, 2000), a forest distributed in the warmtemperate and cool-temperate regions. Floristically, they share broadleaved evergreen and deciduous genera such as Alnus, Arbutus, Cornus, Fraxinus, Garrya and Quercus. The climate of the TRF-biome in North America is cool and maritime, with abundant winter rainfall (Temperate and Mediterranean macrobioclimates) (RivasMartínez, Rivas-Sáenz \& Penas, 2011) and considerable summer cloudiness (little rain) and fog (Whittaker, 1975). These two last attributes coincide partly with the A. jaliscana forest, which exhibits little rainfall in winter, high 
Table 5. Annual mean temperature (AMT) and annual precipitation (AP) in forests with Abies and other conifers.

\begin{tabular}{|c|c|c|c|c|c|}
\hline Location & Latitude & $\begin{array}{l}\text { Elevation (m } \\
\text { a.s.1.) }\end{array}$ & $\operatorname{AMT}\left({ }^{\circ} \mathrm{C}\right)$ & $\mathrm{AP}(\mathrm{mm})$ & Species/ Genus \\
\hline $\begin{array}{l}\text { Sierra de Grazalema } \\
\text { Natural Park, Spain }\end{array}$ & $36^{\circ}$ & $900-1400$ & 15 & 2000 & Abies pinsapo \\
\hline $\begin{array}{l}\text { Sierra of } \\
\text { Zapaliname, Mexico }\end{array}$ & $25^{\circ}$ & $2668-3025$ & $12-13$ & $560-600$ & Abies vejarii \\
\hline $\begin{array}{l}\text { Sierra Nevada, } \\
\text { Mexico }\end{array}$ & $19^{\circ}$ & $3100-3500$ & $10-12$ & $900-1000$ & Abies religiosa \\
\hline $\begin{array}{l}\text { South-Central B. C., } \\
\text { Canada }\end{array}$ & $51^{\circ}$ & $1890-1950$ & 1 & $>1000$ & Abies lasiocarpa \\
\hline $\begin{array}{l}\text { Bull Creek, } \\
\text { California, USA }\end{array}$ & $41^{\circ}$ & 31 & 14 & 1460 & Abies grandis \\
\hline $\begin{array}{l}\text { Headwaters Forest } \\
\text { Reserve, California, } \\
\text { USA }\end{array}$ & $40^{\circ}$ & 482 & 10.3 & 1671 & Abies grandis \\
\hline $\begin{array}{l}\text { Humboldt County, } \\
\text { California, USA }\end{array}$ & $40^{\circ}-41^{\circ}$ & - & $15.9-15.0$ & $\begin{array}{l}1222- \\
1679\end{array}$ & Abies grandis \\
\hline $\begin{array}{l}\text { Qinling Mountains, } \\
\text { China }\end{array}$ & $33^{\circ}$ & $2300-2800$ & $1-6$ & $950-1200$ & Abies fargesii \\
\hline Eastern Asia & - & - & $10-13$ & - & Abies and Tsuga \\
\hline $\begin{array}{l}\text { Upper belt Western } \\
\text { Jalisco, Mexico* }\end{array}$ & $20^{\circ}$ & $2300-2413$ & $13.2-14.5$ & $\begin{array}{l}1183- \\
1217\end{array}$ & Abies jaliscana \\
\hline $\begin{array}{l}\text { Hokkaido, northern } \\
\text { Japan }\end{array}$ & $43^{\circ}$ & - & $5.2-0.7$ & $769-1298$ & $\begin{array}{l}\text { Abies } \\
\text { sachalinensis }\end{array}$ \\
\hline $\begin{array}{l}\text { Mount Shizumo, } \\
\text { central Japan }\end{array}$ & $35^{\circ}$ & $400-500$ & 12.6 & 1813 & Abies firma \\
\hline
\end{tabular}

See references (Wolfe, 1979; Arista, 1995; Noss, 2000; Pelt and Franklin, 2000; Antos and Parish, 2002; Sánchez-González \& López-Mata, 2003; Encina-Domínguez et al., 2008; Dang et al., 2010; Takahashi, 2010; Takahashi and Okuhara, 2012; Berrill, Beal, LaFever \& Dagley, 2013). (*) This study, data were obtained at WorldClim based on coordinates of this study

fog incidence throughout the year, although the highest rainfall occurs in summer and autumn by the influence of tropical macrobioclimate. Nevertheless, in our study area there is an increase in precipitation of the coldest quarter of the year and fir basal area in relation to elevation. This slight increase in winter rainfall suggests more condensation of moist air at higher elevations compared to lower sites, thus favoring the growth of fir trees. The seasonality is different between TRF of Northwestern North America and the western Mexican fir forests; for the North American TRF the entrance of fog occurs in summer (dry period) (Dawson, 1998), whereas in A. jaliscana forests, the fog incidence occurs during the winter-spring period (dry). In both forest biomes this phenomenon is due to their proximity to the ocean. The mix of angiosperms and gymnosperms in the canopy layer is also characteristic of other temperate forests highly influenced by the oceanic moisture, e.g. in New Zealand, Tasmania and southern Chile, which have been described as Oceanic Temperate Forests (OTF) by McGlone, Buitenwerf \& Richardson (2016), but these forests, due to their higher latitude, lack a marked dry season (precipitation of the driest month exceeds $35 \mathrm{~mm}$ ). In contrast, the $A$. jaliscana forests of western Mexico exhibit a precipitation of the driest month less than 7 $\mathrm{mm}$ (WorldClim database). The precipitation of the warmest quarter and precipitation of the coldest quarter of the year are very important variables, because provide information about 
the annual wet-dry threshold and fir forests are mesic, therefore need humidity throughout the year. In summary, due to such climatic and floristic affinities with humid temperate forests, including Abies in the northern hemisphere and to similar temperature and precipitation parameters, it is plausible naming Abies jaliscana forests as temperatelike biome islands within the Subtropical-type bioclimate region.

\section{Conclusion}

In conclusion, the fir forests in Cerro La Bufa and Laguna Juanacatlan, as in the rest of Mexican fir forests of the TMVB, are linked to warm-cool temperate belts, similar to the observed in other forests like those dominated by Abies firma in central Japan or the North American temperate rain forest biome, dominated by Abies grandis (in the same Sect. Grandis, such as A. jaliscana). Our study suggests that the elevation increase (above $2000 \mathrm{~m}$ ), winter rainfall, persistent moisture throughout the year, annual precipitation above $1100 \mathrm{~mm}$ and low mean temperatures $\left(14.5-13.8^{\circ} \mathrm{C}\right)$ in subtropical latitudes, enable a suitable habitat for Jaliscan fir forests; however, other environmental factors such as dispersal, competition and human impact might also play an important role.

Finally, the fir forest in Laguna Juanacatlan seems to be in a healthy condition of conservation, and the forest should be able to maintain itself if not severely disturbed by humans. Global climate change and anthropogenic disturbances such as logging and grazing, could contribute to reduce the extension of Mexican fir forests given that the upward migration of their populations, especially A. jaliscana, would not be possible since they grow almost in the mountain summits. The relationship between winter precipitation and dominance of A. jaliscana represents a high climatic fragility, because under climate change scenarios it is predicted a decrease in winter precipitation and increases in temperature, which negatively affects early wood and late growth in $A$. religiosa and Pinus hartwegii in central Mexico (Astudillo-Sánchez, Villanueva-Díaz, Endara-Agramont, Nava-Bernal \& GómezAlbores, 2017; Carlón-Allende, VillanuevaDíaz, Mendoza \& Pérez-Salicrup, 2018). Therefore, we recommend protecting and conserving the A. jaliscana forests until new research is carried out; which should include more environmental variables and address relationships between climate and growth estimators, such as dendrochronological studies.

\section{References}

Aguirre-Planter, É., Jaramillo-Correa, J.P., Gómez-Acevedo, S., Khasa, D.P., Bousquet J., \& Eguiarte, LE. (2012). Phylogeny, diversification rates and species boundaries of Mesoamerican firs (Abies, Pinaceae) in a genus-wide context. Molecular Phylogenetics and Evolution, 62(1), 263-274.

Allen, S. T., Kirchner, J. W., Braun, S., Siegwolf, R. T., \& Goldsmith, G. R. (2019). Seasonal origins of soil water used by trees. Hydrology and Earth System Sciences, 23(2), 1199-1210.

Antos, J.A. \& Parish, R. (2002). Structure and dynamics of a nearly steady-state subalpine forest in south-central British Columbia, Canada. Oecologia, 130(1), 126-135.

Arista, M. 1995. The structure and dynamics of an Abies pinsapo forest in southern Spain. Forest Ecology and Management, 74(1-3), 81-89.

Astudillo-Sánchez, C.C., Villanueva-Díaz, J., Endara-Agramont, A.R., Nava-Bernal, G.E., \& Gómez-Albores, MA. (2017). Climatic variability at the treeline of Monte Tláloc, México: a dendrochronological approach. Trees, 31(2), 441-453.

Ávila, C.H., Aguirre, J.R., \& García, E. (1994). Variación estructural del bosque de oyamel (Abies hickelii Flous \& Gaussen) en relación con factores ambientales en el Pico de Orizaba, México. Investigación Agraria, Sist. Rec. For., 3(1), 5-17.

Berrill, J.P., Beal, C.B., LaFever, D.H., \& Dagley, C.M. (2013). Modeling Young Stand Development towards the Old-Growth Reference Condition in Evergreen MixedConifer Stands at Headwaters Forest Reserve, California. Forests, 4(2), 455-470.

Carlón-Allende, T., Villanueva-Díaz, J., Mendoza, M.E., \& Pérez-Salicrup, D.R. (2018). Climatic signal in earlywood and latewood in conifer forests in the Monarch Butterfly Biosphere Reserve, México. Tree-Ring Research, 74(1), 63-75.

Chhetri, P.K., Bista, R., \& Cairns, D.M. (2016). Population structure and dynamics of Abies spectabilis at treeline ecotone of Barun Valley, Makalu Barun National Park, Nepal. Acta Ecologica Sinica, 36, 269-274.

Cogbill, C.V. \& White, P.S. (1991). The latitudeelevation relationship for spruce-fir forest and treeline along the Appalachian mountain chain. Vegetatio, 94(2), 153-175. 
Colwell, R. (2015). EstimateS: Statistical estimation of species richness and shared species for samples. Version 9.1.0. http://viceroy.eeb.uconn.edu/estimates/

Cuevas-Guzmán, R., Cisneros-Lepe, E.A., JardelPeláez, E.J., Sánchez-Rodríguez, E.V., Guzmán-Hernández, L., Núñez-López, N.M., \& Rodríguez-Guerrero, C. (2011). Análisis estructural y de diversidad en los bosques de Abies de Jalisco, México. Revista Mexicana de Biodiversidad, 82(4), 1219-1233.

Dang, H., Zhang, Y., Zhang, K., Jiang, M., \& Zhang, Q. (2010). Age structure and regeneration of subalpine fir (Abies fargesii) forest across and altitudinal range in the Qinling Mountains, China. Forest Ecology and Management, 259(3), 547-554.

Dawson, TE. (1998). Fog in the California redwood forest: ecosystem inputs and use by plants. Oecologia, 117(4), 476-485.

Encina-Domínguez, J.A., Encina-Domínguez, F.J., Mata-Rocha, E., \& Valdés-Reyna J. (2008). Aspectos estructurales, composición florística y caracterización ecológica del bosque de oyamel de la Sierra de Zapalinamé, Coahuila, México. Boletín de la Sociedad Botánica de México, 83(1), 13-24.

Gaire, N.P., Koirala, M., Bhuju D.R., \& Borgaonkar H.P. (2014). Treeline dynamics with climate change at the central Nepal Himalaya. Climate of the Past, 10, 1277-1290

Giménez de Azcárate, J. \& Ramírez, I. (2004). Análisis fitosociológico de los bosques de oyamel [Abies religiosa (H. B. K.) Cham. \& Schlecht.] de la Sierra de Angangueo, región central de México. Fitosociologia, 41(1), 91100.

Giménez de Azcárate, J., Macías-Rodríguez, M.A., \& Gopar-Merino, F. (2013). Bioclimatic belts of Sierra Madre Occidental (México): A preliminary approach. International Journal of Geobotanical Research, 3(1), 19-35.

Goldsmith, G. R., Matzke, N. J., \& Dawson, T. E. (2013). The incidence and implications of clouds for cloud forest plant water relations. Ecology letters, 16(3), 307-314.

Gómez-Tuena, A., Orozco-Esquivel, M.T., \& Ferrari L. (2005). Petrogénesis ígnea de la Faja Volcánica Transmexicana. Boletín de la Sociedad Geológica Mexicana, 57(3), 227283.

González-Villarreal, L. M. (2018). Dos nuevas especies de encinos (Quercus: Fagaceae), adicionales para la Flora de Jalisco y Áreas Colindantes, en el Occidente de México. Ibugana: Boletín del Instituto de Botánica de la Universidad de Guadalajara, 9, 47-71.

Gotsch, S. G., Asbjornsen, H., Holwerda, F., Goldsmith, G. R., Weintraub, A. E., \& Dawson, T. E. (2014). Foggy days and dry nights determine crown-level water balance in a seasonal tropical montane cloud forest. Plant, Cell \& Environment, 37(1), 261-272.

Graham, A. (1999). The tertiary history of the northern temperate element in the northern Latin America biota. American Journal of Botany, 86(1), 32-38.

Guerrero-Hernández, R., González-Gallegos, J.G., \& Castro-Castro, A. (2014). Análisis florístico de un bosque de Abies y el bosque mesófilo de montaña adyacente en Juanacatlán, Mascota, Jalisco, México. Botanical Sciences, 92(4), 541-562.

Guerrero-Hernández, R. (2016) Distribución de comunidades de bosque mesófilo de montaña y de Abies en dos gradientes altitudinales del occidente de Jalisco, México [master's thesis]. Zapopan (JAL): Universidad de Guadalajara.

Hartshorn, GS. (1988). Tropical and subtropical vegetation of Meso-America. In North American Terrestrial Vegetation (1st ed.) (p. 365-390). Cambridge. Cambridge University Press.

Hijmans, R.J., Cameron, S.E., Parra, J.L., Jones, P.G., \& Jarvis, A. (2005). Very high resolution interpolated climate surfaces for global land areas. International Journal Climatology, 25(15), 1965-1978.

Holdridge, L. (1947). Determination of world plant formations from simple climatic data. Science. 105(2727), 367-368.

Kneeshaw, D.D. \& Bergeron, Y. (1998). Canopy gap characteristics and tree replacement in the southeastern boreal forest. Ecology, 79(3), 783-794.

Lara-González, R., Sánchez-Velásquez, L.R., \& Corral-Aguirre, J. (2009) Regeneration of Abies religiosa in canopy gaps versus understory, Cofre de Perote National Park, México. Agrociencia, 43(7), 739-747.

Leopold, A.S. (1950). Vegetation zones of Mexico. Ecology, 31(4), 507-518.

Liang, E., Wang, Y., Xu, Y., Liu, B., \& Shao, X. (2010). Growth variation in Abies georgei var. smithii along altitudinal gradients in the Sygera Mountains, southeastern Tibetan Plateau. Trees, 24(2), 363-373.

Linares, J.C., Carreira, J.A., \& Ochoa, V. (2011). Human impacts drive forest structure and diversity. Insights from Mediterranean mountain forest dominated by Abies pinsapo (Boiss). European Journal of Forest Research, 130(4), 533-542.

Lomolino, M.V., Riddle, B.R., Whittaker, R.J. \& Brown, J.H. (2010). Biogeography. Sunderland (MA): Sinauer.

Martínez, M. 1948. Los Abies mexicanos. Anales del Instituto de Biología, Universidad Nacional Autónoma de México, Serie Botánica. 19, 11-104. 
McCune, B. \& Grace, J.B. (2002). Analysis of ecological communities. Gleneden Beach (OR): MjM Software.

McGlone, M.S., Buitenwerf, R., \& Richardson S.J. (2016). The formation of the oceanic temperate forests of New Zealand. New Zealand Journal of Botany, 54(2), 128-155.

Noss, R.F. (2000). The redwood forest: history, ecology, and conservation of the coast redwoods. Washington (DC): Island Press.

Ohsawa, M. (1991). Structural comparison of tropical montane rain forests along latitudinal and altitudinal gradients in south and east Asia. Vegetatio, 97(1), 1-10.

Ohsawa, M. (1995). The montane cloud forest and its gradational changes in southeast Asia. In Tropical Montane Cloud Forests (1st ed.) (p. 254-265). New York (NY): Springer-Verlag.

Olvera-Vargas, M., Figueroa-Rangel, B.L., \& Vázquez-López, J.M. (2010). Is there environmental differentiation in the Quercusdominated forest of west-central Mexico? Plant Ecology, 211(2), 321-335.

Pauley, E.F. \& Clebsch, E.E.C. (1990). Patterns of Abies fraseri regeneration in a Great Smoky Mountains spruce-fir forest. Bulletin of the Torrey Botanical Club, 117(4), 375-381.

Peinado, M., Bartolomé, C., Delgadillo, J., \& Aguado, I. (1994). Pisos de vegetación de la Sierra de San Pedro Mártir, Baja California México. Acta Botánica Mexicana, 29, 1-30.

Peinado, M., Díaz, G., Delgadillo, J., OcañaPeinado, F.M., Macías, M.Á., Aguirre, J.L., \& Aparicio, A. (2012). Bioclimate-Vegetation Interrelations along the Pacific Rim of North America. American Journal of Plant Sciences, 3, 1430-1450.

Pelt, R.V. \& Franklin, J.F. (2000). Influence of canopy structure on the understory environment in tall, old-growth, conifer forests. Canadian Journal of Forest Research, 30(8), 1231-1245.

QGIS Development Team. (2018). QGIS Geographic Information System, v.2.18. Open Source Geospatial Foundation. URL http://qgis.org

Rivas-Martínez, S., Rivas-Sáenz, S. \& Penas, A. (2011). Worldwide bioclimatic classification system. Global Geobotany.

Rushforth, K.D. (1989). Two new species of Abies (Pinaceae) from western Mexico. Notes from the Royal Botanic Garden Edinburgh, 46(1), 101-109.

Rzedowski, J. (1978). Vegetación de México. Editorial Limusa, México, DF

Sánchez-Velásquez, L.R., Pineda-López, M.R., \& Hernández-Martínez, A. (1991). Distribución y estructura de la población de Abies religiosa (H. B. K.) Schl. et Cham., en el Cofre de
Perote, estado de Veracruz, México. Acta Botánica Mexicana, 16,45-55.

Sánchez-González, A. \& López-Mata, L. (2003). Clasificación y ordenación de la vegetación del norte de la Sierra Nevada, a lo largo de un gradiente altitudinal. Anales del Instituto de Biología, Universidad Nacional Autónoma de México, Serie Botánica, 74, 47-71.

Sánchez-González, A., López-Mata, L., \& Vibrans, H. (2006). Composición y patrones de distribución geográfica de la flora del bosque de oyamel del cerro Tláloc, México. Boletín de la Sociedad Botánica de México, 79, 67-78.

Shrestha, K.B. Chhetri, P.K., \& Bista R. (2017). Growth responses of Abies spectabilis to climate variations along an elevational gradient in Langtang National Park in the central Himalaya, Nepal. Journal of Forest Research, 22(5), 274-281.

SMN. (2017). Servicio Meteorológico Nacional. [accessed in January 2017]. http://smn.cna.gob.mx/.

Stephenson, N.L. (1990). Climatic control of vegetation distribution: The role of the water balance. The American Naturalist, 135(5), 649-670.

Systat Software, Inc. (2008). Sigmaplot 2008. Version 11.0. Point Richmond, San José (CA).

Takahashi, K. (2010). Effects of altitude and competition on growth and mortality of the conifer Abies sachalinensis. Ecological Research, 25(4), 801-812.

Takahashi, K. \& Okuhara, I. (2012). Comparison of climatic effects on radial growth of evergreen broad-leaved trees at their northern distribution limit and co-dominating deciduous broad-leaved trees and evergreen conifers. Ecological Research, 27(1), 125-132.

Taylor, A.H. \& Halpern C.B. (1991). The structure and dynamics of Abies magnifica forests in the southern Cascade Range, USA. Journal of Vegetation Science, 2(2), 189-200.

Toledo-Garibaldi, M. \& Williams-Linera, G. (2014). Tree diversity patterns in successive vegetation types along an elevation gradient in the Mountains of Eastern Mexico. Ecological Research, 29(6), 1097-1104.

Vázquez, J.A. \& Givnish, T.J. (1998). Altitudinal gradients in tropical forest composition, structure and diversity in the Sierra de Manantlán. Journal of Ecology, 86(6), 9991020.

Vázquez-García, J.A., Vargas-Rodríguez, Y.L., \& Aragón, F. (2000). Descubrimiento de un bosque de Acer-Podocarpus-Abies en el municipio de Talpa de Allende, Jalisco, México. Ibugana, 7, 159-183.

Vázquez-García, J.A., Shalisko, V., CuevasGuzmán, R., Muñiz-Castro, M.A., \& MantillaBlandón, M.R. (2014). Abies jaliscana 
(Pinaceae): A new combination in section Grandis and a key to the species of Abies in western Mexico. Phytotaxa, 183(1), 27-36.

Velázquez, A., Toledo, V.M. \& Luna, I. (2000). Mexican temperate vegetation. In North American terrestrial vegetation (2nd ed.) ( $\mathrm{p}$. 573-592). Cambridge: Cambridge Univ. Press.

Williams-Linera, G., Toledo-Garibaldi, M., \& Gallardo-Hernández, C. (2013). How heterogeneous are the cloud forest communities in the mountains of central Veracruz, Mexico. Plant Ecology, 214(5), 685-701.

Whittaker, R.H. (1960). Vegetation of the Siskiyou Mountains, Oregon and California. Ecological Monographs, 30(3), 279-338.

Whittaker, RH. (1975). Communities and Ecosystems. New York (NY): Macmillan.

Whittaker, R.H. \& Niering, W.A. (1975). Vegetation of the Santa Catalina Mountains, Arizona. V. Biomass, Production, and Diversity along the Elevation Gradient, Ecology, 56(4), 771-790.

Wolfe, JA. (1979). Temperature parameters of humid to mesic forests of eastern Asia and relation to forests of other regions of the northern hemisphere and Australasia (No. 1106). US Govt. Print. Off 


\begin{tabular}{|c|c|c|c|c|c|c|c|c|c|c|c|c|c|c|c|c|c|c|c|c|}
\hline & $\begin{array}{l}\text { Site } \\
\text { code }\end{array}$ & & & & & & & & & & & & & & & & & & & \\
\hline Taxa & B1 & B2 & B3 & B4 & B5 & B6 & B7 & B8 & B9 & B10 & J1 & $\mathbf{J} 2$ & J3 & J4 & J5 & J6 & J7 & J8 & J9 & J10 \\
\hline
\end{tabular}

\section{Cupressaceae}

Cupressus lusitanica

Pinaceae

\begin{tabular}{lccccccccccccccccccccc}
\hline Abies jaliscana & 4 & 9 & 8 & 4 & 1 & 14 & 53 & 28 & 57 & 13 & 35 & 8 & 49 & 50 & 59 & 14 & 16 & 53 & 47 & 52 \\
\hline Pinus devoniana & - & - & - & - & - & - & - & - & - & - & - & - & - & - & - & 1 & - & - & - & - \\
\hline Pinus douglasiana & 1 & - & - & - & - & 1 & - & - & - & - & - & 1 & 2 & 2 & 3 & - & - & - & - & - \\
\hline Pinus leiophylla & - & - & - & - & - & - & - & - & - & - & 1 & - & - & - & - & - & - & - & 10 & - \\
\hline Pinus lumholtzii & - & - & - & - & - & - & - & - & - & - & - & - & 3 & - & - & - & - & - & - & - \\
\hline Pinus montezumae & - & - & - & - & - & - & - & - & - & - & - & - & - & - & - & - & - & - & - & 2 \\
\hline Pinus oocarpa & - & - & - & 4 & - & - & - & - & - & - & 3 & - & 2 & - & - & - & - & - & - & - \\
\hline Pinus pseudostrobus & - & - & - & - & - & - & 2 & - & - & 2 & 4 & - & - & - & - & - & 1 & - & 1 & - \\
\hline
\end{tabular}

\section{Magnolids}

\section{Lauraceae}

Persea hintonii

\section{Magnoliaceae}

Magnolia pacifica

Eudicots

\section{Anacardiaceae}

Toxicodendron radicans

\section{Araliaceae}

Oreopanax xalapensi

8




\section{Asteraceae}

Ageratina areolaris

Baccharis salicifolia

Roldana angulifolia

Rumfordia floribunda

Telanthophora jaliscana

Verbesina fastigiata

Aquifoliaceae

Ilex brandegeana

Ilex dugesii

Ilex tolucana

Berberidaceae

Berberis hemsleyi

\section{Betulaceae}

Carpinus caroliniana

Ostrya virginiana

\section{Celastraceae}

\section{Clethraceae}

Clethra fragans

Clethra hartwegii

$-$

\begin{tabular}{llllllllllllllllllll}
3 & 3 & 1 & - & - & - & - & - & - & - & - & - & 1 & 2 & - & - & - & - & - & - \\
- & - & - & 2 & - & - & - & - & - & - & - & - & - & - & - & - & - & - & - & - \\
20 & 8 & 5 & 1 & 1 & - & - & 7 & 14 & 20 & - & - & - & - & - & - & - & - & - & - \\
6 & 4 & 1 & 4 & 1 & - & - & - & - & 1 & - & - & - & - & - & - & - & - & - & - \\
- & - & - & - & 1 & 1 & - & - & - & - & - & - & - & - & - & - & 6 & - & - & 22 \\
2 & - & - & - & - & - & - & - & - & - & - & - & - & - & - & - & - & - & - & - \\
\hline
\end{tabular}

\section{Clusiaceae}

Cornaceae

Cornus disciflora

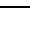

$\begin{array}{lll} & & \\ - & - & - \\ - & 2 & -\end{array}$

$\begin{array}{ll}- & - \\ - & - \\ - & -\end{array}$

Cornus excelsa

\section{Ericaceae}

Arbutus tesellata

Arbutus xalapensis

5

3

Euphorbiaceae

Euphorbia schlechtendalii

Fabaceae

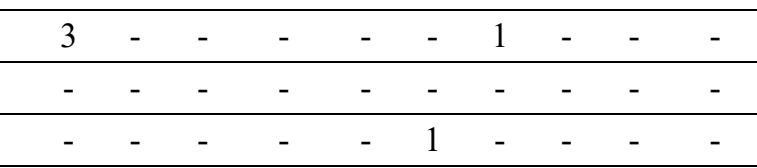

$x^{2}$

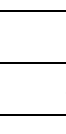

$-$




\begin{tabular}{|c|c|c|c|c|c|c|c|c|c|c|c|c|c|c|c|c|c|c|c|c|}
\hline Calliandra laevis & 2 & - & - & - & - & - & - & - & - & - & - & - & - & - & - & - & - & - & - & - \\
\hline Inga hintonii & 8 & - & - & - & - & - & - & - & - & - & - & - & - & - & - & - & - & - & - & - \\
\hline \multicolumn{21}{|l|}{ Fagaceae } \\
\hline Quercus calophylla & - & 1 & 4 & 2 & - & - & - & - & - & - & 2 & 1 & - & - & - & - & - & 1 & - & 3 \\
\hline Quercus castanea & - & - & - & 5 & - & - & - & - & - & - & 3 & - & 2 & 7 & 5 & - & 1 & 4 & 1 & 5 \\
\hline Quercus crassifolia & - & - & - & - & - & - & 1 & - & 3 & - & - & - & - & - & - & - & - & - & - & - \\
\hline Quercus centenaria & 17 & 9 & 30 & 5 & - & - & - & - & - & - & - & - & - & - & - & - & - & - & - & - \\
\hline Quercus laurina & - & - & - & - & - & - & - & - & - & 3 & - & - & - & - & - & - & - & - & - & - \\
\hline Quercus martinezii & - & - & - & 4 & 16 & 4 & - & - & 15 & - & - & - & - & - & - & - & - & - & - & - \\
\hline Quercus nixoniana & - & - & - & - & - & - & - & 1 & - & - & - & - & - & - & - & - & - & - & - & - \\
\hline Quercus obtusata & - & - & - & 7 & 2 & - & 2 & - & 12 & 1 & 5 & 9 & 4 & 8 & 12 & 2 & - & 3 & 13 & 4 \\
\hline Quercus rugosa & - & - & 1 & 1 & - & 1 & - & - & 15 & 2 & - & - & - & - & - & - & - & - & - & - \\
\hline Quercus scytophylla & - & - & - & - & - & 1 & - & 11 & - & 3 & - & - & - & 1 & - & - & - & - & - & 1 \\
\hline
\end{tabular}

\section{Garryaceae}

Garrya longifolia

Melastomataceae

Conostegia volcanalis

$\begin{array}{lllllllll}- & - & - & - & - & - & 9 & - & 13\end{array}$

$13-\quad-3+3$

$-\quad-1$

- $\quad-1 \quad-$

Miconia albicans

6

Myrtaceae

Eugenia culminicola

Eugenia sp.

Oleaceae

Fraxinus uhdei

Pentaphylacaceae

Cleyera integrifolia

Symplococarpon purpusii

Ternstroemia lineata

-

$-$

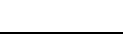

$-$

\section{Primulaceae}

Myrsine juergensenii

$-5$

Rosaceae 
Crataegus mexicana

Prunus cortapico

Prunus serotina subsp. capuli

Glossostipula concinna

Sabiaceae

Meliosma dentata

$-\quad-\quad-\quad-\quad 2$

Styracaceae

Styrax argenteus

$\begin{array}{ccccc}- & - & - & - & - \\ 24 & 12 & 20 & 14 & 6\end{array}$

$50+20$

Styrax radians

$-\quad-$

$-$

$-$

\section{Symplocaceae}

Symplocos citrea

Verbenaceae

Lippia umbellata

\section{Vitaceae}

Vitis sp.

Salicaceae

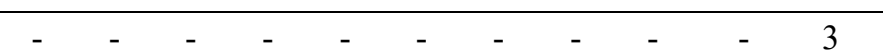

19218

Xylosma flexuosa

Morphospecies 1

Morphospecies 2

(2)

$-\frac{1}{-1}-$

3

